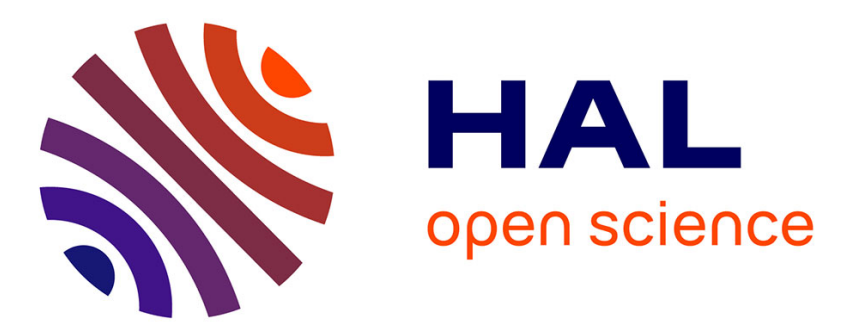

\title{
Electrodeposited birnessite thin film: An efficient eco-friendly sorbent for removing heavy metals from water
}

R. Choumane, Sophie Peulon

\section{- To cite this version:}

R. Choumane, Sophie Peulon. Electrodeposited birnessite thin film: An efficient eco-friendly sorbent for removing heavy metals from water. Colloids and Surfaces A: Physicochemical and Engineering Aspects, 2019, 577, pp.594-603. 10.1016/j.colsurfa.2019.06.013 . hal-02363626

\section{HAL Id: hal-02363626 \\ https://hal.science/hal-02363626}

Submitted on 20 Nov 2020

HAL is a multi-disciplinary open access archive for the deposit and dissemination of scientific research documents, whether they are published or not. The documents may come from teaching and research institutions in France or abroad, or from public or private research centers.
L'archive ouverte pluridisciplinaire HAL, est destinée au dépôt et à la diffusion de documents scientifiques de niveau recherche, publiés ou non, émanant des établissements d'enseignement et de recherche français ou étrangers, des laboratoires publics ou privés. 
Electrodeposited birnessite thin film: An efficient eco-friendly sorbent for

\title{
removing heavy metals from water.
}

R. Choumane ${ }^{a b}$, S. Peulon ${ }^{a b *}$

\begin{abstract}
${ }^{\text {a } U M R ~} 8587$ CNRS, Université Paris Saclay
${ }^{\mathrm{b}}$ Laboratoire Analyse et Modélisation pour la Biologie et l'Environnement (LAMBE), Université d’Évry, Université Paris Saclay, Bd François Mitterrand 91025 Évry Cedex
\end{abstract}

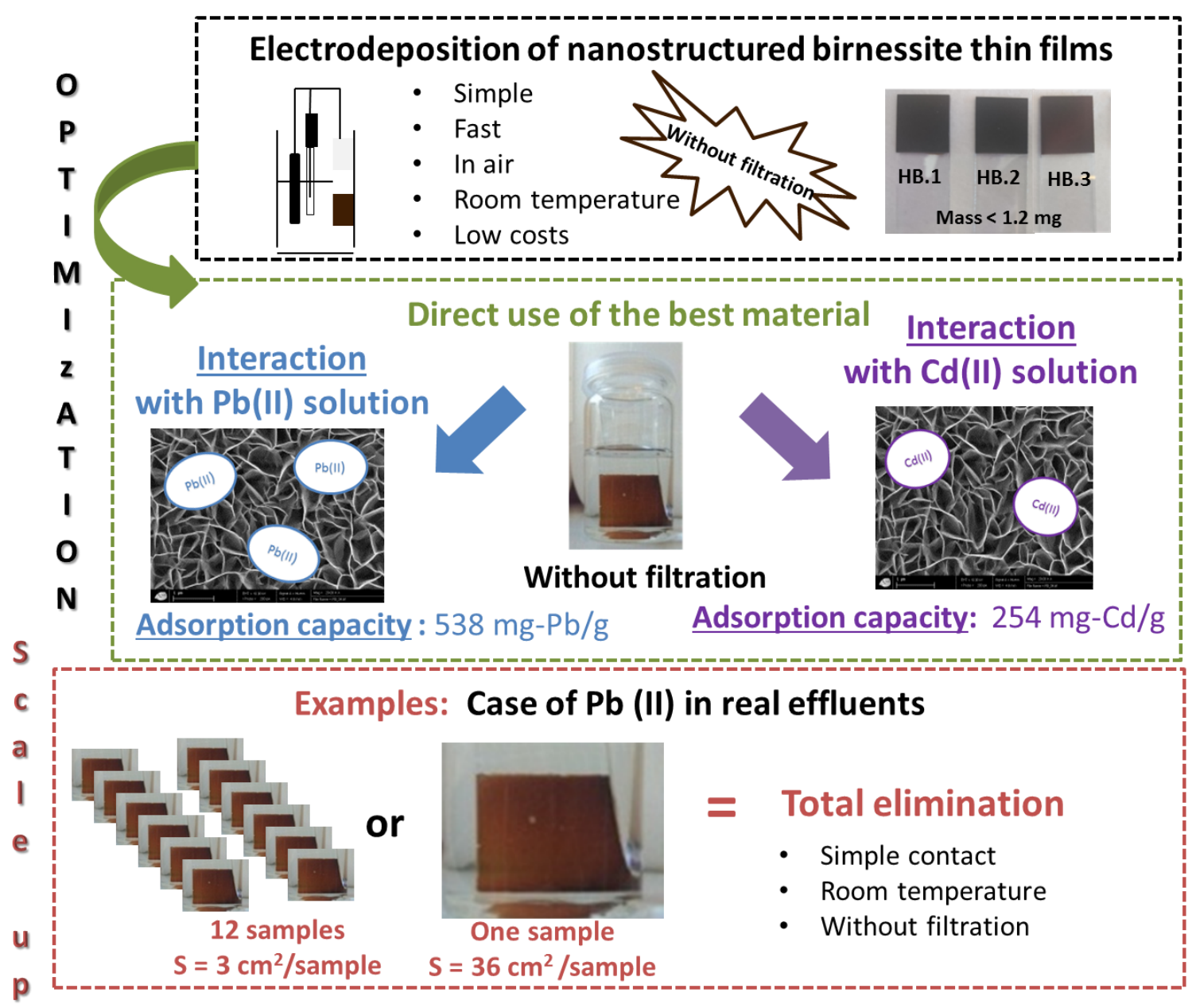




\begin{abstract}
Sorption is an efficient process for transferring heavy metals from polluted water to solid phase. Birnessite, which is a non-toxic layered manganese oxide, is particularly interesting for this objective due to its high sorption capacities towards heavy metals. In this paper, pure and nanostructured birnessite was synthesized as adherent thin films onto a solid substrate by electrochemistry with different characteristics for high sorption (e.g. mass, Average Oxidation State). The sorption of $\mathrm{Pb}$ (II) and $\mathrm{Cd}$ (II) by these films was studied in terms of $\mathrm{pH}$, ionic strength, sorption isotherm and kinetic order. The birnessite thin film with the highest AOS after synthesis (3.76) presents significant adsorption capacity for $\mathrm{Pb}$ (II) (538 mg- $\mathrm{Pb} / \mathrm{g}$ ) and $\mathrm{Cd}$ (II) $(254 \mathrm{mg}-\mathrm{Cd} / \mathrm{g})$. A total decontamination at room temperature without filtration and energy input was obtained on model solutions and real effluents by increasing only the number of samples or the surface of electrodeposited birnessite on one sample. These birnessite thin films appear as very interesting eco-friendly sorbents for eliminating lead and cadmium from polluted aquatic media due to their easy synthesis and optimization process, and the possible reuses by efficient desorption, in very low-cost conditions.
\end{abstract}

KEY WORDS: Layered manganese oxides; Phyllomanganate; Electrodeposition; Heavy metals, Depollution; Wastewater treatment.

* Corresponding author:

tel.: + 331694703 53, fax: +33169477655

Email address: sophie.peulon@univ-evry.fr 


\section{Introduction}

One of the most common soil and groundwater contaminations is due to heavy metals, more particularly by lead and cadmium. These high toxic elements are dangerous for animals and humans in particular that can damage the nervous system and may be carcinogen $[1,2]$. These two metals released from numerous industrial products such as dyes, batteries, metallurgy. Without proper treatment, they can be eventually discharged in the environment, which would be particularly dramatic because they are no (bio)degradable and tend to accumulate in all aquatic and terrestrial environments [2, 3].

There are various technologies for removing heavy metals from aquatic media such as filtration, surface complexation, chemical precipitation, ion exchange and sorption [4-7]. Among these methods, sorption is considered as one of the most important processes transferring heavy metals from aquatic to solid phase, because of its efficiency and economics [8-10]. Numerous adsorbents present high properties of lead, cadmium and other heavy metals sorption such as diatomite [11], carbon nanotubes [12], zeolite [1], bentonite [13], manganese oxides [14], and birnessite in particular [9, 15, 16].

Birnessite, which is a non-toxic lamellar manganese oxide, possesses high adsorption capacities and abilities to remove spontaneously trace metals present in environment due to its very open structure [17-19]. Apart from its excellent heavy metal uptake capacity, it is also interesting because of eco-friendly nature and low costs for its synthesis [20, 21]. There are a lot studies in this field but still need many research opportunities [22]. For example, the required filtration steps after the synthesis of birnessite powder and its use after sorption reaction can be very energetic steps, the recycle and reuse of material after adsorption, and obviously the increasing of the efficient for sorption, etc... Adding, there is no pilot or industrial scale investigations published at this time and there is need more potential research [22]. 
In the literature, the studies concerning lead and cadmium sorption were performed with birnessite powders in classical batch experiments. In this paper, the original methodology proposed is to synthesize birnessite as a thin film deposited onto a solid conductive substrate by electrochemistry, and to use them for developing innovative wastewater treatments. Indeed, such samples present many advantages for these potential applications:

(i) Electrochemistry is a very suitable method for depositing adherent thin films, well crystallized and homogeneous, in very soft, fast and low cost conditions, with a good control of the mass, thickness and intrinsic properties for birnessite [23-31], but also for other materials such as $\mathrm{ZnO}[32,33]$, iron compounds [34], or titanium dioxide [35];

(ii) The thin films avoid filtration after their synthesis and also after their interaction with the contaminated media, which can be very energetic steps and can complicate the decontamination processes;

(iii) The possibility of desorption and reuse of the same sample since the birnessite remains in the form of adherent film onto the solid substrate;

(iv) The possibility to work on large scale simply by increasing the number of samples or the surface of one sample. Indeed, electrochemistry is already a method largely used at large scales in various surface treatment industries (e.g. aeronautic...).

For that, the main objectives of this work were in first to optimize electrodeposited birnessite thin films with the optimal mass of material in the aim to create efficient sorbents for $\mathrm{Pb}$ (II) and $\mathrm{Cd}$ (II) ions removal from aquatic media. Average Oxidation States (AOS) of Mn is also one of the most important parameters: the sorption of heavy metals increases with the oxidation state of Mn $[9,15,16]$. In second part, different parameters that can influence the sorption capacity of $\mathrm{Pb}$ (II) and $\mathrm{Cd}$ (II) ions were studied for the best material. In addition, the 
possibilities of desorption and reuse were studied for the optimized thin film. At the end, the selected material as thin film was tested for treatment of real effluents on larger scales.

\section{Experimental}

\subsection{Chemicals}

Reagents, $\mathrm{MnSO}_{4} \cdot \mathrm{H}_{2} \mathrm{O}$ (ACS Reagent Aldrich), $\mathrm{Na}_{2} \mathrm{SO}_{4} \cdot 10 \mathrm{H}_{2} \mathrm{O}$ (VWR ProLABO chemicals), $\mathrm{NaOH}$ (1M, ACS Reagent Sigma Aldrich), $\mathrm{H}_{2} \mathrm{SO}_{4}$ (1M, ACS Reagent Sigma Aldrich), $\mathrm{NaNO}_{3}$ (VWR ProLABO chemicals), Mohr's salt (ACS Reagent Sigma Aldrich), sodium pyrophosphate (ACS Reagent Sigma Aldrich), potassium permanganate (ACS Reagent Sigma Aldrich), standard solution of $\mathrm{Pb}$ (II) $\left(1002 \pm 4 \mu \mathrm{g} \cdot \mathrm{mL}^{-1}, 5 \% \mathrm{HNO}_{3}\right.$, certified by using High Performance ICP-OES, Alfa Aesar) and standard solution of Cd (II) (1002 $\pm 4 \mu \mathrm{g} . \mathrm{mL}^{-1}$, $5 \% \mathrm{HNO}_{3}$, certified by using High Performance ICP-OES, Alfa Aesar) were used without further purification. All solutions were prepared by using Milli-Q water.

\subsection{Electrodeposited birnessite thin films}

The electrodeposition of birnessite thin films was carried out in a classical electrochemical set-up with three electrodes as described elsewhere [24, 26-29]. The reference electrode was a Mercurous Sulfate Electrode (MSE, E $=0.6513 \mathrm{~V} / \mathrm{ENH}$ ). The working electrode was a glass plate covered with tin dioxide $\mathrm{SnO}_{2}: \mathrm{F}$ (FTO Fluorine-doped Tin Oxide, Solems); the surface in contact with the solution was delimited by an adhesive mask ( $\mathrm{S}=3$ $\mathrm{cm}^{2}$ ). The counter electrode was a platinum wire wound spirally for having a surface equal to the working electrode. All electrochemical syntheses were performed at room temperature using a microautolab potentiostat/galvanostat system controlled by a computer using the GPES software.

The solution was put in the classical electrochemical cell $\left(\left[\mathrm{MnSO}_{4}\right]=1.610^{-3} \mathrm{M}\right.$ in $\left[\mathrm{Na}_{2} \mathrm{SO}_{4}\right]=0.4 \mathrm{M}$, free $\mathrm{pH}$ close to 5.6), and was gently stirred continuously during all 
synthesis. The electrodeposition was performed by oxidation of Mn (II) ions, present in the solution as soluble species, into a Mn (III)/Mn (IV) solid deposited directly onto the conductive substrate as an adherent thin film $[17,36]$. The oxidation reaction was performed by chronoamperometry (constant potential) at fixed electric charges [26, 28-31].

After electrodeposition, the thin films were rinsed with Milli-Q water and dried in ambient air during some hours. After that, the mass of the birnessite thin film was stable and determined by weighing with a precision balance (Sartorius ME and SE Series, Electronic Analytical Balances and Semi-Microbalances). Each measurement was repeated several times to estimate the repeatability and the reproducibility of the electrodeposition.

Average Oxidation States (AOS) of manganese is an important parameter for heavy metals sorption. For that, the AOS of each sample was determined by potentiometric titration in three steps [37]. The thin film of birnessite electrodeposited on substrate was completely dissolved in the Mohr's salt acidified solution under ultrasounds and then titrated with a potassium permanganate solution $\left(1.2510^{-3} \mathrm{M}\right)$ in order to determine the AOS by this potentiometric method [37]. Each measure was repeated several times to estimate the repeatability and reproducibility.

\subsection{Effects of $\mathrm{pH}$, ionic species and temperature on sorption capacities}

One birnessite thin film was introduced into a cell containing $50 \mathrm{mg} . \mathrm{L}^{-1}$ of lead ( $\mathrm{Pb}(\mathrm{II})$ ) or cadmium $(\mathrm{Cd}(\mathrm{II}))$ solution prepared from the standard solution with pure milli-Q water. All experiments were performed at $298 \mathrm{~K}$ under gently stirring. Preliminary studies show that 24 hours was enough to reach the sorption equilibrium.

The $\mathrm{pH}$ of the solution was adjusted with $\mathrm{NaOH}(1 \mathrm{M})$ for studying its influence on sorption: the $\mathrm{pH}$ ranges varied from 1.7 (free) to 5.2 for $\mathrm{Pb}$ (II) or 1.8 (free) to 6.1 for $\mathrm{Cd}$ (II) solution respectively. The adsorption was not performed beyond these $\mathrm{pH}$ values due to the possible precipitation of $\mathrm{Pb}(\mathrm{OH})_{2}$ or $\mathrm{Cd}(\mathrm{OH})_{2}$. 
The effect of ionic species was studied by adding $\mathrm{NaNO}_{3}$ at different concentrations from 0.01 to $1 \mathrm{M}$. The thermodynamic study was performed at temperature varying from 283 to 313 $\mathrm{K}$ in a thermostatic oven. These two studies were done at the fixed optimal $\mathrm{pH}$ (4.2).

No filtration step was required because the birnessite thin film stayed always very adherent on the solid support. Besides, the sorption of $\mathrm{Pb}$ (II) or $\mathrm{Cd}$ (II) onto the substrate alone $\left(\mathrm{SnO}_{2}: \mathrm{F}\right)$ was negligible $(\approx 0.1 \%)$.

\subsection{Desorption studies}

Different parameters can be influenced the possibility to desorb heavy metal from birnessite sample such as the chemical medium and the $\mathrm{pH}$ value. For that, desorption of $\mathrm{Pb}$ (II) and Cd (II) from birnessite thin film was performed either in Milli-Q water or $\mathrm{NaNO}_{3}(1 \mathrm{M})$ solution at different $\mathrm{pH}$ values from 2.5 to 6.2 , by adding $\mathrm{NaOH}(1 \mathrm{M})$ or $\mathrm{H}_{2} \mathrm{SO}_{4}(1 \mathrm{M})$ if necessary. All experiments were carried out at $298 \mathrm{~K}$ under gently stirring for $24 \mathrm{~h}$.

\subsection{Data processing}

The concentration of $\mathrm{Pb}$ (II) or $\mathrm{Cd}$ (II) present in the solution was determined by using the specific Spectroquant ${ }^{\circledR}$ test $\left(1.09717 .0001,0.01-5.00 \mathrm{mg} . \mathrm{L}^{-1} \mathrm{~Pb}\right.$ Spectroquant ${ }^{\circledR}$ and 1.01745.0001, 0.01-0.50 mg. $\mathrm{L}^{-1} \mathrm{Cd}$ Spectroquant ${ }^{\circledR}$; absorbance measurements at wavelength $520 \mathrm{~nm}$ by a spectrophotometer for $\mathrm{Pb}(\mathrm{II})$ and $\mathrm{Cd}(\mathrm{II}))$. The amount of heavy metal adsorbed onto the electrodeposited thin film of birnessite was calculated by the difference between the initial amount and equilibrium one using Eq. 1:

$$
\mathrm{n} \text { M(II) adsorbed }=\mathrm{n} \mathrm{M}(\mathrm{II}) \text { initial }-\mathrm{n} \mathrm{M}(\mathrm{II}) \text { equilibrium at } \mathrm{t}
$$

With $\mathrm{n}$ in mol, and $\mathrm{t}$, corresponding to a fixed duration

The sorption capacity was calculated using Eq.2:

$$
\mathrm{Qe}=\frac{(C 0-C e) V}{m}
$$


With $\mathrm{Q}_{\mathrm{e}}$, the sorption capacity $\left(\mathrm{mg} \cdot \mathrm{g}^{-1}\right)$; $\mathrm{C}_{0}$, the initial concentration of $\mathrm{Pb}$ (II) or $\mathrm{Cd}$ (II) $\left(\mathrm{mg} . \mathrm{L}^{-1}\right) ; \mathrm{C}_{\mathrm{e}}$, the concentration at the equilibrium time $\left(\mathrm{mg} . \mathrm{L}^{-1}\right) ; \mathrm{V}$, the volume of the solution (L); $\mathrm{m}$, the mass of the electrodeposited birnessite thin film onto the solid substrate (g).

The amount of $\mathrm{Pb}$ (II) or $\mathrm{Cd}$ (II) adsorbed at equilibrium was studied at different temperatures (298-318K) to determine the thermodynamic parameters for the adsorption process, from Eq.3, Eq.4 and Eq.5:

$$
\begin{array}{cc}
\mathrm{Kd}=\frac{Q e}{C e} & \text { Eq.3 } \\
\ln K d=\frac{\Delta \mathrm{S}}{R}+\frac{\Delta \mathrm{H}}{R T} & \text { Eq.4 } \\
\Delta \mathrm{G}=\Delta \mathrm{H}-\mathrm{T} \Delta \mathrm{S} & \mathbf{E q . 5}
\end{array}
$$

With $\mathrm{Kd}$, the distribution coefficient for the adsorption; $\Delta \mathrm{S}$, the entropy; $\Delta \mathrm{H}$, the enthalpie; $\Delta \mathrm{G}$, the Gibbs energy; $\mathrm{T}$, the temperature $(\mathrm{K}) ; \mathrm{R}$ the gas constant $\left(\mathrm{J} \mathrm{mol}^{-1} \mathrm{~K}^{-1}\right)$.

The desorption of $\mathrm{Pb}$ (II) or $\mathrm{Cd}$ (II) from birnessite thin film was calculated as follows, Eq.6:

$$
\text { M (II)desorbed }(\%)=\frac{m M(I I) d}{m M(I I) a} * 100
$$

With $\mathrm{m}_{\mathrm{M}(\mathrm{II}) \mathrm{d}}$ and $\mathrm{m}_{\mathrm{M}(\mathrm{II}) \mathrm{a}}(\mathrm{mg})$, the amounts of $\mathrm{M}(\mathrm{II})$ (Pb (II) or Cd (II)) desorbed and adsorbed onto birnessite thin film respectively.

\subsection{Characterizations of birnessite thin film by GIXRD, SEM and EDS analysis}

Before and after sorption, the crystal structure of the thin films was characterized by Grazing Incidence X-ray Diffraction GIXRD $\left(\lambda_{\mathrm{Cu}}=1.540600 \AA\right)$. The nanostructures of materials were observed by Scanning Electron Microscopy (SEM) using a JEOL JSM-6100. These observations were supplemented by Energy Dispersive Spectroscopy analyzes (EDS). 
The distribution of the heavy metals on the sample after sorption experiments was analyzed by elementary cartography. All characterizations were carried out directly without any preparation step since the material was sufficient conductive.

\section{Results and discussion}

\subsection{Optimization of electrodeposited birnessite thin films}

In our previous studies, we have demonstrated that pure and very homogeneous of wellcrystallized $\mathrm{H}$-birnessite $\left(\mathrm{Mn}_{7} \mathrm{O}_{13} .5 \mathrm{H}_{2} \mathrm{O}\right)$ can be electrodeposited in aqueous solutions $\left(\mathrm{NaSO}_{4}\right.$ as electrolyte) by chronoamperometry at fixed electrical charges [25, 26, 28-31]. The general principle of the electrodeposition is based on the oxidation of Mn (II) ions soluble present in the solution into a direct Mn (III) / Mn (IV) solid deposited onto a conductive substrate as an adherent thin film, according to Eq. 7, [25].

$$
7 \mathrm{Mn}(\mathrm{II})+13 \mathrm{H}_{2} \mathrm{O} \longrightarrow \mathrm{Mn}_{7} \mathrm{O}_{13} .5 \mathrm{H}_{2} \mathrm{O}+26 \mathrm{H}^{+}+12 \mathrm{e}^{-} \quad \text { Eq. } 7
$$

These electrodeposited thin films are very efficient for the degradation of organic pollutants by spontaneous redox reactions on their surface [26, 28-31]. The optimal samples for these applications have been synthetized by chronoamperometry $(\mathrm{E}$ imposed $=0.6 \mathrm{~V})$ with 1.8 Coulombs, as fixed electric charge, onto a FTO surface equal to $\left.S=3 \mathrm{~cm}^{2}\left(0.6 \mathrm{C}_{\mathrm{cm}}\right)^{2}\right)[28,29]$.

These experimental conditions were used for the synthesis of sample named HB.1 in this study. The mass of H-birnessite electrodeposited was equal to $1.1710^{-3} \mathrm{~g}$, Table $\mathbf{1}$, in good agreement with the expected theoretical mass calculated according to the Faraday's law (Eq.8) for this value of Q, Figure 1:

$$
\mathrm{m}=\frac{Q}{n \cdot F} \cdot \mathrm{M}
$$

Eq. 8 
with $\mathrm{m}$, the theoretical mass; $\mathrm{Q}$, the electric charge (Coulombs); $\mathrm{n}$, the number of electrons required for the formation of one mole of H-birnessite; F, Faraday constant (96485 C.mol $\left.{ }^{-1}\right) ; \mathrm{M}$, molar mass of $\mathrm{H}$-birnessite $\left(\mathrm{Mn}_{7} \mathrm{O}_{13} .5 \mathrm{H}_{2} \mathrm{O}\right),[31]$.

The thickness of the electrodeposited material on the solid substrate is directly proportional to the mass, and can be calculated according to the Eq. 9, [31, 39], Table 1.

$$
\mathrm{e}=\frac{m / s}{\rho}
$$

With e, the thickness of the electrodeposited thin film $(\mathrm{cm}) ; \mathrm{m}$, the mass of the thin film $(\mathrm{g})$; $\mathrm{s}$, the surface of the film $\left(3 \mathrm{~cm}^{2}\right)$ and $\rho$, the density of birnessite $\left(3 \mathrm{~g} . \mathrm{cm}^{-3}\right)$.

The Mn Average Oxidation States determined for this sample is equal to 3.60, Table 1, a value comparable to the natural birnessite found in soils [9, 23, 40]. Previous characterizations of this type of sample (HB.1) by different techniques such as XRD, XPS and XANES/EXAFS spectroscopy confirm systematically the formation of a very well crystallized and pure H-birnessite [41, 42].

The objective of the present paper is to develop H-birnessite thin films with high sorption properties towards heavy metals such as $\mathrm{Pb}$ (II) and $\mathrm{Cd}$ (II) ions. For that, it was necessary to found the best compromise between the optimal amount of the sorbent and a high value of AOS. For reaching these objectives, the fixed electric charged was decreased for the same value of fixed potential.

Table 1 resumes the experimental conditions and the values of the Mn Average Oxidation States of each sample determined by the potentiometric method described in the experimental section. The AOS varies from 3.60 (HB.1) to 3.76 (HB.3). For each condition, current measured is well stable and constant during all the duration confirming a systematic 
good electronic conduction of the electrodeposited material. After synthesis, all samples are homogenous and adherent, with experimental masses directly proportional to the value of the fixed electric charge, and close to the expected theoretical masses, confirming that the faradic yield and the precipitation yield are close to $100 \%$ even for low values of Q, Figure 1. Moreover, recent ex situ XAS measurements have confirmed that independently of the amount of matter ( $\mathrm{Q}$ fixed varied from $0.06 \mathrm{C} / \mathrm{cm}^{2}$ to $0.6 \mathrm{C} / \mathrm{cm}^{2}$ ), the structure of $\mathrm{H}$-Birnessite stayed identical for this value of potential [41, 42]. These experimental conditions for electrodeposition of birnessite thin films seem interesting for the fixed objectives: good adherence, well reproducibility and rapidity of the synthesis ( $<<1$ hour).

\subsection{Sorption studies}

\subsubsection{Effect of the mass and AOS of electrodeposited material on sorption capacities}

The differences between these three types of samples are the mass of material and the AOS of Mn. Therefore, it was important to determine the best material with the higher capacity of $\mathrm{Pb}$ (II) and $\mathrm{Cd}$ (II) sorption. For that, one sample of each type was introduced into a solution containing lead or cadmium $\left(50 \mathrm{mg} \cdot \mathrm{L}^{-1}\right)$, with the $\mathrm{pH}$ adjusted at 4.2 by adding $\mathrm{NaOH}(1 \mathrm{M})$. The sorption studies were performed at $298 \mathrm{~K}$ under stirring during $24 \mathrm{~h}$. Figures 2 A and 2 B shows that HB.3 sample with the highest value of AOS (3.76) and the lowest mass of electrodeposited material $\left(0.3310^{-3} \mathrm{~g}\right)$ presents better adsorption capacities for $\mathrm{Pb}$ (II) and $\mathrm{Cd}$ (II) ions. Therefore, only this type of sample was used for determining the kinetic and the influence of interaction conditions.

\subsubsection{Effect of $\mathrm{pH}$ and ionic species on sorption reaction}

Birnessite has a Point of Zero Charge (PZC) close to 2-3 [43, 44]. The point of zero charge corresponds to the $\mathrm{pH}$ value when the surface is neutral. Below this $\mathrm{pH}$, the birnessite surface has a positive surface density and hence a repulsion towards cationic species. Above 
this $\mathrm{pH}$, the birnessite surface has a negative surface density and so an attraction for cationic species. That is why this study of the $\mathrm{pH}$ was important. Moreover, $\mathrm{pH}$ has a direct effect on the chemistry of lead and cadmium, (e.g. formation of hydroxides complexes) [45].

These experimental studies concerning the influence of $\mathrm{pH}$ were performed by using one sample of HB.3 put into a solution containing one heavy metal (50 mg. $\left.\mathrm{L}^{-1}\right)$, presenting different $\mathrm{pH}$ values from 1.7 (free) to 5.2 by adding $\mathrm{NaOH}(1 \mathrm{M})$ for $\mathrm{Pb}$ (II), and from 1.86 (free) to 6.12 by adding $\mathrm{NaOH}(1 \mathrm{M})$ for $\mathrm{Cd}$ (II). In these ranges of $\mathrm{pH}, \mathrm{Pb}$ (II) and $\mathrm{Cd}$ (II) are present as cationic species, [46]. Figure 3 shows that better adsorption capacities were obtained for $\mathrm{pH}$ superior to $\mathrm{PZC}$ as expected. The value of $\mathrm{pH}$ equal to 4.2 seems interesting for obtaining significant sorption and was chosen in the rest of this study for $\mathrm{Pb}$ (II) and $\mathrm{Cd}$ (II) studies. It was noticed that the $\mathrm{pH}$ of the solution after $\mathrm{Pb}$ (II) or $\mathrm{Cd}$ (II) sorption has a little decrease, which can be attributed to exchange between heavy metal and $\mathrm{H}^{+}$that exists onto the birnessite sites.

The influence of ionic species was studied during the interaction of one sample of HB.3 with lead or cadmium solutions $\left(50 \mathrm{mg} \cdot \mathrm{L}^{-1}\right)$ at $\mathrm{pH}=4.2$ by adding $0.01,0.1$ and $1 \mathrm{M}$ of $\mathrm{NaNO}_{3}$ salt. The sorption capacities show that the presence of $\mathrm{Na}^{+}$ion has no significant effect on the adsorption capacity of HB.3 sample even at high concentration (not shown). This means that the sorption of $\mathrm{Pb}$ (II) or $\mathrm{Cd}$ (II) onto birnessite thin film is still efficient in presence of competitive cations and would not be affected in the case of effluents charged with salt.

\subsubsection{Sorption kinetics}

Two kinetic orders are proposed generally in the literature for data interpretation concerning birnessite in powder form [38]: a pseudo-first order (Eq.10) and a pseudo-second order (Eq.11):

$$
\operatorname{Ln}\left(\mathrm{q}_{\mathrm{e}}-\mathrm{q}_{\mathrm{t}}\right)=\operatorname{Ln}\left(\mathrm{q}_{\mathrm{e}}\right)-\mathrm{k} . \mathrm{t} \quad \text { Eq. } 10
$$


With $\mathrm{q}_{\mathrm{e}}$ and $\mathrm{q}_{\mathrm{t}}$, the amounts of $\mathrm{Pb}$ (II) or Cd (II) adsorbed by the solid (e.g. birnessite thin films) $(\mathrm{mg} / \mathrm{g})$ at equilibrium and at time $\mathrm{t}(\mathrm{min})$, and $\mathrm{k}$, the rate constant of the pseudo-first order model $\left(\mathrm{min}^{-1}\right)$.

$$
\mathrm{t} / \mathrm{q}_{\mathrm{t}}=1 / \mathrm{k}^{\prime} \mathrm{q}_{\mathrm{e}}^{2}+\mathrm{t} / \mathrm{q}_{\mathrm{e}}
$$

With $\mathrm{k}$, the rate constant of the pseudo-second order model $\left(\mathrm{mg} \cdot \mathrm{g}^{-1} \cdot \mathrm{min}^{-1}\right)$.

Kinetic experiments sorption were investigated by using one sample of the bestselected material (HB.3). Figure 4 shows that the pseudo-second order of $\mathrm{Pb}$ (II) and $\mathrm{Cd}$ (II) adsorption by the birnessite thin film HB.3 $\left(\mathrm{R}^{2}=0.9996\right.$ and 0.9939 respectively) is well adapted. The rate constants $\mathrm{k}$ ' are equal to $3.4310^{-5} \mathrm{mg} \cdot \mathrm{g}^{-1} \cdot \mathrm{min}^{-1}$ for $\mathrm{Pb}$ (II) and $1.7610^{-5} \mathrm{mg} \cdot \mathrm{g}^{-}$ ${ }^{1} \cdot \mathrm{min}^{-1}$ for $\mathrm{Cd}$ (II) sorption. The difference in the values indicates a better affinity of $\mathrm{Pb}$ (II) for HB.3 sample than Cd (II). These results confirm the mechanism of chemisorption in good agreement with the studies of the literature based on birnessite powders, [2, 44].

\subsubsection{Sorption isotherms}

The shape of the adsorption isotherm reveals the nature of the interactions during adsorption processes. Among the eighteen types of isotherms listed in the Giles classification [45], there are two typical forms for the adsorption in solution: Langmuir and sigmoid [48].

Sorption isotherm experiments were performed for evaluating $\mathrm{Pb}$ (II) and $\mathrm{Cd}$ (II) sorption capacities on HB.3 sample. Figures $\mathbf{5} \mathbf{A}$ and $\mathbf{5 B}$ prove that the adsorption isotherm is the sigmoid type for $\mathrm{Pb}$ (II) and Cd (II) sorption by the birnessite thin film HB.3. The two observed concavities could be explained by the presence of two different types of sorption sites [47, 48]. The maximal adsorption capacity by one thin film of birnessite HB.3 can be determined from the isotherm plateau. The values are equal to $(538 \pm 20) \mathrm{mg} \cdot \mathrm{g}^{-1}$ for $\mathrm{Pb}$ (II) and $(254 \pm 11) \mathrm{mg} . \mathrm{g}^{-1}$ for Cd (II) ions respectively. These values indicate that one HB.3 birnessite thin film possesses great sorption capacities in comparison to results presented in the literature 
with powders of birnessite or also others manganese oxides, Table 2. Moreover, the synthesis of such HB. 3 samples is fast $(\approx 12$ minutes), performed in very soft conditions without steps of filtration neither after the synthesis nor after the interaction with heavy metals, which are great advantages for future applications at very low costs.

\subsection{Characterization of materials by GIXRD, SEM and EDS analysis.}

GIXRD measurements of HB.3 sample after synthesis confirm the formation of pure and crystallized $\mathrm{H}$-birnessite $\left(\mathrm{Mn}_{7} \mathrm{O}_{13} .5 \mathrm{H}_{2} \mathrm{O}\right)$ by the presence of two characteristic peaks at $12.2^{\circ}$ and $36.4^{\circ}$ according to JCPDS 23-1239 card, Figure 6. The other peaks correspond to the $\mathrm{SnO}_{2}: \mathrm{F}$ substrate according to JCPDS 41-1445 card. The HB.3 samples containing the maximal amount of adsorbed heavy metal ( $\mathrm{Pb}$ (II) or $\mathrm{Cd}$ (II)) were also characterized by GIXRD. After adsorption of $\mathrm{Pb}$ (II) ions (HB.3-Pb), the first peak at $12.2^{\circ}$ is absent and the second peak at $36.4^{\circ}$ is widened. This can be due to a slight loss of crystallinity of the sample after sorption of lead. However, after Cd (II) sorption (HB.3-Cd), the characteristic peak of the H-birnessite at $12.2^{\circ}$ is still present, whereas the second characteristic peak of the H-birnessite at $36.4^{\circ}$ becomes also wider, certainly due to the same reasons, Figure 6.

SEM characterization of HB.3 before sorption reports that the sample is very homogeneous and nanostructured with the characteristic sheets of birnessite [17]. The crystal sizes vary from $70 \mathrm{~nm}$ to $80 \mathrm{~nm}$ in thickness, and from $1.0 \mu \mathrm{m}$ to $1.2 \mu \mathrm{m}$ in length, Figure 7 . The observations of the samples containing the maximal amount of heavy metal after adsorption (noted HB.3-Pb and HB.3-Cd respectively) show that the nanostructure are not modified (no presence of nanoparticules and/or precipitates), Figure 7.

To complete, EDS analyses of the HB.3 samples before and after sorption of $\mathrm{Pb}$ (II) or Cd (II) were performed, Figure 8. The EDS analysis of HB.3 sample reveals the presence of small amount of $\mathrm{Na}(4.6 \%)$. XRD characterization confirms the synthesis of H-Birnessite, 
however, it may be possible that a few amount of Na-birnessite could be formed in view of the synthesis medium (presence of $0.4 \mathrm{M} \mathrm{Na}_{2} \mathrm{SO}_{4}$ as electrolyte). The analysis of samples HB.3Pb and HB.3-Cd after sorption confirms the presence of lead and cadmium $(4.4 \%$ and $2 \%$ respectively), a formal proof of heavy metals sorption by HB.3 birnessite thin film, Figure 8 . In addition, elementary cartographies of $\mathbf{H B . 3 - P b}$ and $\mathbf{H B . 3 - C d}$ samples were performed at 3000 and 20000 magnifications respectively. These elementary cartographies confirm the homogeneous distribution of each chemical element such as $\mathrm{Mn}, \mathrm{O}$, and $\mathrm{Pb}$ or $\mathrm{Cd}$ over the entire surface without precipitate, Figure 9.

\subsection{Thermodynamic studies}

To study the thermodynamic aspect of the adsorption of $\mathrm{Pb}$ (II) and $\mathrm{Cd}$ (II) ions by the HB. 3 birnessite thin film, experiments were carried out at different temperatures: $283 \mathrm{~K}, 298 \mathrm{~K}$ and $313 \mathrm{~K}$ by using a thermostatic oven. The sorption studies were made with stirring for 24 hours using one HB.3 sample in interaction with $50 \mathrm{~mL}$ of solution containing $6.5 \mu \mathrm{mol}$ of heavy metal ions ( $\mathrm{Pb}$ (II) or $\mathrm{Cd}$ (II)) corresponding to $26.91 \mathrm{mg} . \mathrm{L}^{-1}$ and $14.56 \mathrm{mg} / \mathrm{L}$ respectively, whose the $\mathrm{pH}$ was adjusted to 4.2 by addition of $\mathrm{NaOH}(1 \mathrm{M})$.

Whatever the adsorbed heavy metal, $\mathrm{Pb}$ (II) or $\mathrm{Cd}$ (II), the increase of temperature enhances the kinetics of adsorption, Figures 10A and 10B respectively. Indeed, this increase in temperature favours the overall progress of the adsorption process by the HB.3 birnessite thin film, and more significantly in the case of lead. From the evolution of $\ln \mathrm{Kd}$ versus $1 / \mathrm{T}$, Figure 11, it was possible to deduce the thermodynamic parameters relating to the adsorption of $\mathrm{Pb}(\mathrm{II})$ or $\mathrm{Cd}$ (II) by the HB.3 birnessite thin film, such as Gibbs energy $(\Delta \mathrm{G})$, enthalpy $(\Delta \mathrm{H})$, and entropy $(\Delta S)$, using Eq. 3, 4 and 5. These values are summarized in Table 3.

Negative values of $\Delta \mathrm{G}$ indicate that the adsorption process by the HB.3 birnessite thin film is spontaneous. The degree of spontaneity of the reaction enhances with temperature 
attributed to an increase of the sites number in the active surface available on the adsorbent, and to the decrease in the thickness of the layer surrounding the adsorbent with temperature $[52,53]$.

Positive values of $\Delta \mathrm{H}$ indicate the endothermic behaviour of the adsorption reaction. This fact is proved by the increased of $\mathrm{Pb}$ (II) and $\mathrm{Cd}$ (II) sorption with temperature. Positive values of $\Delta \mathrm{H}$ suggest also that a large amount of heat is consumed to transfer $\mathrm{Pb}$ (II) and $\mathrm{Cd}$ (II) ions from the aqueous solution to the solid phase.

Positive values of $\Delta \mathrm{S}$ reflect the affinity of birnessite samples for $\mathrm{Pb}$ (II) or $\mathrm{Cd}$ (II). The cations must release of their water hydration before their interaction with the surface. Such release of water from $\mathrm{Pb}$ (II) or $\mathrm{Cd}$ (II) cations results in positive values of $\Delta \mathrm{S}$. It is further noted that the value of $\Delta \mathrm{S}$, in the case of cadmium, is lower than that for lead, traducing a greater affinity of the HB.3 film for $\mathrm{Pb}$ (II) than for $\mathrm{Cd}$ (II). This result can be globally explained in the following way: the exchange of $\mathrm{Pb}$ (II) or $\mathrm{Cd}$ (II) with $\mathrm{H}^{+}$requires the breaking of binding of $\mathrm{OH}$ groups on the birnessite surface, which is an endothermic process. In addition, the sorption of $\mathrm{Pb}$ (II) or $\mathrm{Cd}$ (II) requires a diffusion process, which is an endothermic process that is why the increasing in temperature favours the sorption of $\mathrm{Pb}$ (II) or $\mathrm{Cd}$ (II) in the birnessite structure $[52,53]$.

\subsection{Desorption studies}

The desorption of $\mathrm{Pb}$ (II) or Cd (II) present in HB.3 samples (HB.3-Pb and HB.3-Cd respectively) was carried out at $298 \mathrm{~K}$ for 24 hours with stirring, either in milli-Q water or in a $\mathrm{NaNO}_{3}$ solution $(1 \mathrm{M})$, with $\mathrm{pH}$ values ranging from 2.5 to 6.2 by adding $\mathrm{H}_{2} \mathrm{SO}_{4}(1 \mathrm{M})$ or $\mathrm{NaOH}$ (1M) if necessary. These experimental choices $\left(\mathrm{NaNO}_{3}\right.$ and acidic $\left.\mathrm{pH}\right)$ are based on our experimental results and on the intrinsic properties of birnessite: the $\mathrm{pH}$ can play on the charge of the surface $(\mathrm{PZC})$ and the presence of sodium ions and $\mathrm{H}^{+}$can favour mainly their insertion at the expense of heavy metal. 
The maximal desorption of heavy metals from HB.3 samples whether the heavy metal $(\mathrm{Pb}$ (II) or $\mathrm{Cd}(\mathrm{II}))$ was obtained at $\mathrm{pH}=2.5$, in good agreement with the $\mathrm{PZC}$ of birnessite, and in a $\mathrm{NaNO}_{3}$ solution. In these conditions, the desorption after $24 \mathrm{~h}$ was estimated to $\approx 70 \%$ in the case of $\mathrm{Pb}(\mathrm{II})$, and $\approx 50 \%$ in the case of $\mathrm{Cd}$ (II), Figures $12 \mathrm{~A}$ and $12 \mathrm{~B}$. In addition, the reuse of the same sample of HB.3 was tested for four times with adsorption / desorption cycle, and the adsorption efficiency remains similar for these four cycles in both cases ( $\mathrm{Pb}$ (II) or $\mathrm{Cd}$ (II)).

\subsection{Application: Interests of this sorbent for number up and/or scale up?}

A study was carried out by increasing the number of birnessite thin films (HB.3) put into an aqueous solution containing $6.5 \mu \mathrm{mol}$ of lead $\left(26.91 \mathrm{mg} . \mathrm{L}^{-1}\right)$. The initial $\mathrm{pH}$ was adjusted at 4.2 and the solution was stirring for 24 hours at $298 \mathrm{~K}$, Figure 13. The amount of $\mathrm{Pb}(\mathrm{II})$ adsorbed increases with the number of samples to reach a total decontamination of the solution after 24 hours at room temperature by simple contact of 12 samples of HB.3 without any filtration steps. An equivalent solution of $\mathrm{Pb}$ (II) was treated with only one sample of HB.3 electrodeposited onto a total surface of $36 \mathrm{~cm}^{2}$, an equivalent surface of $12 \mathrm{HB} .3$ samples. A total elimination of $\mathrm{Pb}$ (II) of the solution was also obtained after 24 hours at $298 \mathrm{~K}$. Similar tests were carried out with success on two real samples containing lead and cadmium coming from CSTB (Centre Scientifique et Technique du Bâtiment - Nantes France) and wastewater treatment plant, confirming the good ability to eliminate these heavy metals even in real wastewaters.

\section{Conclusion}

Adherent birnessite thin films were synthesized by a fast electrochemical method at room temperature and at low costs. The better type HB.3 thin film presents higher $\mathrm{Pb}$ (II) and Cd (II) sorption capacity compared to equivalent powder birnessite in term of AOS. This high 
sorption capacity compared to powders may be explained by the nanostructuration of the surface and/or the very low quantities of the solid $(0.33 \mathrm{mg})$. Moreover, these thin films are very interesting for obtaining a total decontamination of solutions containing $\mathrm{Pb}$ (II) without filtration steps by increasing only the number of samples or the surface of the electrodeposited birnessite on one sample introduced into the solution. In addition, desorption of heavy metals is possible in very simple conditions leading to possible reuses with similar efficiency.

Due to their simple conditions of synthesis and optimization process, these ecofriendly materials are very encouraging for efficient $\mathrm{Pb}$ (II) and $\mathrm{Cd}$ (II) removal from polluted aquatic media at very low-costs.

\section{Acknowledgements}

Thanks go to V. Ji for XRD characterization (ICMMO - CNRS - UPSud), R. Pires for SEM observations, EDS and elementary cartography analyses (ICMPE - CNRS - UMR 7182), N. Legarrec and A. Couzinet for providing the real samples from CSTB (Nantes-France), and A. Masy for providing the real samples from wastewater treatment plant (Evry- France).

\section{References}

[1] Effect of $p H$, ionic strength and temperature on sorption of Pb (II) on NKF-6 zeolite by batch technique. X. Yang, Shubing Yang, Shitong Yang, J. Hu, X. Wang. 2011, Chem. Eng. J. 168, 86-93.

[2] Sorption characteristics of lead cations on microporous organo-birnessite. C-Y Lee, T. Kim, S Komarneni, S-K. Han, Y. Cho. 2013, Applied Clay Science, 263, 83-84.

[3] M (II) transfer across a liquid-liquid microinterface facilitated by a complex formation with 8-Hydroxyquiniline; Application to quantification of $\mathrm{Pb}(\mathrm{II}), \mathrm{Cd}(\mathrm{II})$ and $\mathrm{Zn}(\mathrm{II})$ alone or in mixture in effluents. A. Mastouri, S. Peulon, N. Bellakhal, A. Chaussé. 2014, Electrochim. Acta, 130, 818-825. 
[4] Effect of pH and aging time on the Kinetic dissociation of 243 Am (III) from humic acide coated gamma- $\mathrm{Al}_{2} \mathrm{O}_{3}$ a chelating resin exchange study. X. K. Wang, C. L. Chen, J.Z. Du, X. L. Tan, D. Xu, S. M. Yu. 2005, Environ. Sci. Technol., 39, 7094-7088.

[5] Removal of heavy metal ions from water by complecation- assisted ultrafiltration. $\mathbf{K}$. Trivunac, S. Stevanovic. 2006, Chemosphere 64, 486-491.

[6] Using of chelating resin to study the kinetic desorption of Eu (III) from humic acid- $\mathrm{Al}_{2} \mathrm{O}_{3}$ colloid surfaces. X.K. Wang, X. Zhou, J.Z. Du, W.P. Hu, C.L. Chen, Y.X. Chen. 2006, Surf. Sci., 600, 478-483.

[7] Selective removal of the heavy metal ions from waters and industrial wastewaters by ionexchange methode. A. Dabrowski, Z. Hubicki, P. Podkoscielny, E. Robens. 2004, Chemosphere, 56, 91-106.

[8] $\mathrm{Pb}^{2+}$ adsorption on birnessite affected by $\mathrm{Zn}^{2+}$ and $\mathrm{Mn}^{2+}$ pretratements,. W. Zhao, Q. Q. Wang, F. Liu, G. Hong Qio, W.F. Tan, X. H.Feng. 2010, J. Soils Sediments, 10, 870-878.

[9] XAFS studies on surface coordination of $\mathrm{Pb}^{2+}$ on birnessite with different average oxidation states. W. Zhao, W. Tan, X Feng, F. Liu, Y. Xie. 2011, Colloids and Surfaces A : Physicochem. Eng. Aspects, 379, 86-92.

[10] Synthesis and characterization of radiation grafted films for removal of arsenic and some heavy metals from contaminated water. M.N.K. Chowdhury, M. W. Khan, M. F. Mina, M. D. H. Beg, M. R. Khan, A.K.M.M. Alam. 2012, J. Radiation Physics and Chemistry, 81, 16061611.

[11] Adsorption of $\mathrm{Pb}$ (II) on diatomite as effected via aqueous solution chemistry and temperature . G. Sheng, S.Wang, J. Hu, Y. Lu, J. Li, Y. Dong, X. Wang. 2009, Colloids and surface A: Physicochem. Eng. Aspects, 339, 159-166.

[12] Adsorption thermodynamic, kinetic and desorption studies of $\mathrm{Pb}^{2+}$ on carbon nanotubes. Y.H. Li, Z.C. Di, J. Ding, D.H. Wu, Z.K. Luan, Y. Q. Zhu. 2005, Water Res., 39, 605-609.

[13] Influence of $\mathrm{pH}$, soil humic/fulvid acid, ionic strength, foreign ions and addition sequences on adsorption of $\mathrm{Pb}$ (II) onto GMZ bentonite. S. Wang, J. Hu, J. Li, Y. Dong. 2009, J. of Hazardous Materials, 167, 44-51.

[14] Removal of lead (II) from aqueous solution by adsorption onto manganese oxide-coated carbon nanotubes. S.G. Wang, W.X. Gong, X.W. Yao, B.Y. Yue. 2007, Sep. Purif. Technol. $58,17-23$.

[15] Sorption behavior of heavy metals on birnessite: Relationship with its Mn average oxidation state and implications for types of sorption sites. Y. Wang, X. Feng, M. Villalobos, W. Tan, F. Liu. 2012, Chemical Geology, 292-293, 25-34. 
[16] Relation of lead adsorption on birnessite with different average oxidation states of manganese and release of $\mathrm{Mn}^{2+} / \mathrm{H}^{+} / \mathrm{K}^{+}$. W. Zhao, X. Feng, W. Tan, F. Liu, S. Ding. 2009, Journal of Environmental Sciences, 21, 520-526.

[17] Manganese oxide minerals: Crystal structures and economic and environmental signifiance. J. Post. 1999, Proc . Natl. Acad. Sci. USA, 96, 3447-3454.

[18] Biogenic manganese oxides: Properties and mecanisms of formation. B.M. Tebo, J.R. Bargar, B.G. Clement, G.J. Dick, K.J. Murray, D. Parker, R. Verity, S.M. Webb. 2004, Annu. Rev Earth Planet Sci. 32, 287-328.

[19] A novel nanostructured Fe-Ti-Mn composite oxide for highly efficient arsenic removal: Preparation and performance evaluation. W. Zhang, C. Liu, L.Wang' T. Zheng, G. Ren' J. Li J.Ma' G. Zhang, H. Song, Z. Zhang, Z. Li. 2019, Colloids and Surfaces A: Physicochemical and Engineering Aspects. 561, 364-372.

[20] Manganese oxide-based materials as electrochemical supercapacitor electrodes. W. Wei, X. Cui, W. Chen, D.G. Ivey. 2011, Chem. Soc. Rev. 40, 1697-1721.

[21] Incorpration of Manganese Dioxide within Ultraporous Activated Graphene for HighPerformance Electrochemical Capacitors. X. Zhao, L. Zhang, S. Murali, M.D. Stoller, Q. Zhang, Y. Zhang, Y. Zhu, R.S. Ruoff. 2012, ACS Nano, 6, 5404-5412.

[22] Manganese oxides and their application to metal ion and contaminant removal from wastewater. Md.A. Islam, D.Morton, B. Johnson, B. Mainali, M. J. Angove. 2018, Journal of Water Process Engineering, Vol. 26, 264-280.

[23] Advances in Electrochemistry and Electrochemical Engineering, 3. D.A. Vermilyea, P. Delhay (Ed.). 1963, Interscience Publishers, Chapitre 4.

[24] Iron compounds electrodeposited onto a transparent semiconductor: Synthesis and characterisation by UV-vis spectroscopy. S. Peulon, Q. Braize, A. Chaussé. 2007, Electrochimica Acta, 52, 7681-7688.

[25] Studies on electrodeposition from Mn (II)species of thin layers of birnessite onto transparent semiconducteur. N. Larabi-Gruet, S. Peulon, A. Lacroix, A. Chaussé. 2007, Electrochim. Acta, 52, 7681-7688.

[26] Studies of $N$-demethylation oxidative and degradation of methylene blue by thin layers of birnessite electrodeposited onto $\mathrm{SnO}_{2}$. M. Zaied, S. Peulon, N. Bellakhal, B. Desmazières, A. Chaussé. 2011, Applied Catalysis B : Environmental, 101, 441-450.

[27] Electrophoretic deposition of siderite thin layers: Influence of electrode potential and deposition time, 518. A. Ithurbide, S. Peulon, F. Miserque, C. Beaucaire, A. Chaussé, Ch. Poinssot. 2010, Thin Solid Films, 2644-2648. 
[28] Degradation of glyphosate and AMPA (amino methylphosphonic acid) solutions by thin films of birnessite electrodeposited onto $\mathrm{SnO}_{2}$. M. Ndjeri, A. Pensel, S. Peulon, V. Haldys, B. Desmazières, A. Chaussé. 2011, Applied Catalaysis B : Environmental, 107, 42-51.

[29] Efficient electrochemical treatment based on electrodeposited thin films of birnessite for mineralisation of AMPA (aminomethylphosphonic acid) in very soft conditions. A. Pensel, S. Peulon, A. Chaussé. 2016, Electrochemistry Communications, 69, 19-23.

[30] Spontaneous oxidative degradation of indigo caramine by thin films of birnessite electrodeposited onto $\mathrm{SnO}_{2}$. M. Zaied, E. Chutet, S. Peulon, N. Bellakhal, B. Desmazières, M. Dachraoui, A. Chaussé. 2011, Applied Catalysis B : Environmental, 107, 42-51.

[31] Synthèses et caractérisations des oxydes de manganèse déposés en couches minces par voie électrochimique : Application à la dépollution des effluents industriels chargés en colorants organiques, Ph.D, Université d'Evry Val d'Essonne. M. Zaeid Salem. 2012.

[32] Mechanistic Study of Cathodic Elecfrodeposition of Zinc Oxide and Zinc Hydroxychioride Films from Oxygenated Aqueous Zinc Chloride Solutions. S. Peulon, D. Lincot. 1998. J. Electrochem. Soc., Vol. 145, 864-874.

[33] Microstructures and photocatalytic properties of $\mathrm{ZnO}$ films fabricated by $\mathrm{Zn}$ electrodeposition and heat treatment. T. Wanotayan, J. Panpranot, J Qin, Y. Boonyongmaneerat. Materials Science in Semiconductor Processing, 74 : s.n.2018, Materials Science in Semiconductor ProcessingMaterials Science in Semiconductor ProcessingMaterials Science in Semiconductor Processing, 232-237.

[34] Iron compounds electrodeposited onto a transparent semiconductor: Synthesis and characterisation by UV-vis spectroscopy. S. Peulon, Q. Baraize, A. Chaussé. 2007, Electrochimica Acta, 52, 7681-7688.

[35] Preparation of titanium dioxide thin films by indirect-electrodeposition. M. Chigane, T. Shinagawa, J. Tani. 2017, Thin Solid Films, 628, 203-207.

[36] Electrochemical synthesis of birnessite-type layered manganese oxides for rechargeable lithium batteries. M. Nakayama, T. Kanaya, J.W. Lee, B. N. Popov. 2008, Journal Of Power Sources, Vol. 179, 361-366.

[37] Caracterisation structural de la birnessite : Influence du protocole de synthèse. A.C. Gaillot. 2002, Ph. D, Université Joseph Fourier-Grenoble, France .

[38] Pseudo-second order model for sorption processes. Y. S. Ho, G. Mckay. 1999, Process Biochemistry, 34, 451-465.

[39] Birnessite, a new manganese oxide mineral from Aberdeenshire. LHP Jones, AA Milne. 1956, Scotland. Mineralogical Magazine, Vol. 31, 283-288.

[40] In-situ X-rayabsorption study of the mechanism of Cr (III) oxidation at the Mn oxide/water interface. A. Manceau, L. Charlet. 1990, Chemical Geology, 84, 275-278. 
[41] PhD. "Films électrodéposés d'oxydes de manganèse : application à la dégradation des polluants émergents dans l'environnement. A. Pensel. Nov 2016, Thèse de doctorat de l’Université Paris-Saclay préparée à l'Université d'Evry-Val-d'Essonne, France.

[42] In situ XANES measurements during electrodeposition of thin film: Example of birnessite, a promising material for environmental application. A. Pensel, S. Peulon. 2018, Electrochimica Acta, Vol. 281, 738-745.

[43] Linking solid phase speciation of Pb sequestered to birnessite to oral Ob bioaccessibilit: Implications fot soil remediation. D. G. Beak, N. T. Basta, Lirk G. Scheckel, SJ. Traina. 2008, Environ. Sci. Technil. 42, 779-785.

[44] Adsorption of copper, cadmium, lead and zinc onto a synthetic manganese oxide. L.Della Puppa, M. Komarek, F. Bordas, J-C. Bollinger, E. Joussein. 2013, Journal of colloid and interface Science, 399, Vol. 399, 99-106.

[45] Mise en oeuvre controlée des réactions dans les operations de chimie en solution. B. Tremillon, 1989.

[46] Applied Complexometry, Pergamon Press, 1982, Analytical Applications of EDTA and Related Compounds, Pergamon Press, R.Pribil, 1972.

[47] A general treatment and classification of the solute adsorption isotherm I. C.H. Giles, D. Smith, A. Huitson. 1974; , Theoretical, 47, 755-765.

[48] Chapitre Twelve - Porous Texture and surface characterization from Liquide-Solid Interactions: Immersion Calorimetry and adsorption from solution, adsorption bt carbons. $\mathbf{R}$. Denoyel, F. Rouquerol. 2008, 273-300.

[49] Use of hydrous manganese dioxide as a potential sorbent for selective removal of lead, cadmium, and zinc ions from water. Q. Su, B. Pan, S. Wan, W. Zhang, L. Lv. 2010, Journal of Colloid and Interface Science, 349, 607-612.

[50] Magnetic manganese dioxide as an amphoteric adsorbent for removal of harmful inorganic contaminants from water. C. A. C. Rosas, M. Franzreb, F. Valenzuela, W. H. Höll. 2010, Reactive \& Functional Polymers, 70, 516-520.

[51] Adsorption and redox reactions of heavy metals on synthesized Mn oxide minerals, X.H. Feng, L.M. Zhai, W.F. Tan, F. Liu, J.Z. He. 2007, Environmental Pollution, 147, 366-373.

[52] Synthesis, structural characterisation and $\mathrm{Pb}$ (II) adsorption behavior of $\mathrm{K}$ - and $\mathrm{H}$ birnessite samples. E. Eren, H. Gumus, A. Sarihan. 2011, Desalination, Vol. 279, 75-85.

[53] Kinetic and thermodynamic study of the adsorption of Red195 and Metylene blue dyes on fly ash and bottom ash in aqueous medium. A. Aarfane, A. Salhi, M. El Krati, S. Tahiri, M.

Monkade, E.K. Lhadi, M. Bensitel. 2014, J. Mater. Environ. Sci. Vol. 6, 1927-1939. 


\section{Tables:}

Table 1: Conditions for synthesis of each type of birnessite thin film electrodeposited at $\mathrm{E}=$ $0.6 \mathrm{~V}$ onto $\mathrm{SnO}_{2}: \mathrm{F}$ solid substrate, the experimental mass, the thickness of electrodeposited thin film (e) and the Average Oxidation States (AOS)

\begin{tabular}{cccccccc}
\hline Sample & $\mathbf{Q}(\mathbf{C})$ & $\mathbf{t}(\mathbf{s})$ & $\begin{array}{c}\text { Experimental } \\
\text { mass } \\
\mathbf{x 1 0 ^ { - 3 }}(\mathbf{g})\end{array}$ & $\begin{array}{c}\mathbf{e} \\
\mathbf{x 1 0} \\
(\mathbf{c m})\end{array}$ & $\begin{array}{c}\text { AOS } \\
( \pm \mathbf{0 , 0 5})\end{array}$ & $\begin{array}{c}\text { Mn } \\
\text { IV } \\
(\boldsymbol{\%})\end{array}$ & $\begin{array}{c}\text { Mn } \\
\text { III }\end{array}$ \\
\hline HB.1 & 1.80 & $\approx 2400$ & 1.17 & 0.130 & 3.60 & 60 & 40 \\
HB.2 & 0.90 & $\approx 1200$ & 0.60 & 0.066 & 3.66 & 66 & 34 \\
HB.3 & $\mathbf{0 . 4 5}$ & $\approx \mathbf{7 0 0}$ & $\mathbf{0 . 3 3}$ & $\mathbf{0 . 0 3 7}$ & $\mathbf{3 . 7 6}$ & $\mathbf{7 6}$ & $\mathbf{2 4}$ \\
\hline
\end{tabular}


Table 2: Adsorption capacity and experimental parameters for removing $\mathrm{Pb}$ (II) and $\mathrm{Cd}$ (II) by using manganese oxides (Birnessite, Todorokite, Cryptomelane, Hausmannite) in powder form (literature) in comparison to electrodeposited birnessite thin films (HB.3) (this study)

\begin{tabular}{cccccc} 
Sorbents & \multicolumn{3}{c}{ Adsorption conditions } & Adsorption capacity & References \\
& $\mathbf{t}(\mathbf{h})$ & $\mathbf{p H}$ & $\mathbf{T}(\mathbf{K})$ & & \\
\hline Electrodeposited & 24 & 4.2 & 298 & $\mathbf{P b}(\mathbf{I I}): 538 \mathrm{mg} \cdot \mathrm{g}^{-1}$ & This study \\
birnessite thin film & & & & $2600 \mathrm{mmol} . \mathrm{kg}^{-1}$ & \\
HB.3 type & & & & $\mathbf{C d ~ ( I I ) : ~} 254 \mathrm{mg} \cdot \mathrm{g}^{-1}$ & \\
& & & & $2200 \mathrm{mmol} . \mathrm{kg}^{-1}$ & \\
\end{tabular}

Birnessite powder $\quad 24 \quad 5.5 \quad 298 \quad$ Pb (II): $435 \mathrm{mg} \cdot \mathrm{g}^{-1}$

Cd (II): $146 \mathrm{mg} \cdot \mathrm{g}^{-1}$

$24 \quad 2-8 \quad 298 \quad$ Pb (II): $332 \mathrm{mg} \cdot \mathrm{g}^{-1}$

Cd (II): $135 \mathrm{mg} \cdot \mathrm{g}^{-1}$

$34298 \quad$ Pb (II): $145 \mathrm{mg} \cdot \mathrm{g}^{-1}$

[50]

Cd (II): $34 \mathrm{mg} \cdot \mathrm{g}^{-1}$

$24 \quad 4.5 \quad 298 \quad$ Pb (II): $2646 \mathrm{mmol} . \mathrm{kg}^{-1}$

Cd (II): 1057 mmol. $\mathrm{kg}^{-1}$

[15]

$24 \quad 4.5 \quad 298 \quad \mathbf{P b}$ (II): $1832 \mathrm{mmol} \cdot \mathrm{kg}^{-1}$

Cd (II): 1042 mmol. $\mathrm{kg}^{-1}$

\section{Others manganese}

oxides powders

Todorokite

$\begin{array}{lll}24 & 4.5 & 298\end{array}$

Pb (II): 284.3 mmol. $\mathrm{kg}^{-1}$

Cd (II): $85.1 \mathrm{mmol} . \mathrm{kg}^{-1}$

[51]

Cryptomelane

$24 \quad 4.5 \quad 298$

Pb (II): 292 mmol. $\mathrm{kg}^{-1}$

Cd (II): $88.8 \mathrm{mmol} . \mathrm{kg}^{-1}$

Hausmannite

$24 \quad 4.5 \quad 298$

Pb (II): 105.3 mmol. $\mathrm{kg}^{-1}$

Cd (II): 3.3 mmol. $\mathrm{kg}^{-1}$

[51] 
Table 3: Thermodynamic parameters of $\mathrm{Pb}$ (II) and $\mathrm{Cd}$ (II) adsorption by using electrodeposited birnessite thin film (HB.3)

\begin{tabular}{|c|c|c|c|c|c|}
\hline \multirow[t]{2}{*}{ Metal ions } & \multirow[t]{2}{*}{$\Delta \mathrm{H}\left({\left.\mathrm{KJ} . \mathrm{mol}^{-1}\right)}^{-1}\right.$} & \multirow[t]{2}{*}{$\Delta S\left(J^{\prime} \mathrm{mol}^{-1} \cdot \mathrm{K}^{-1}\right)$} & \multicolumn{3}{|c|}{$\Delta G\left(K^{\prime} . m^{-1}\right)$} \\
\hline & & & $283 K$ & $298 K$ & 313K \\
\hline $\mathbf{P b}$ (II) & 67.54 & 251.63 & -3.66 & -7.44 & -11.22 \\
\hline Cd (II) & 19.68 & 86.01 & -4.66 & -5.95 & -7.24 \\
\hline
\end{tabular}




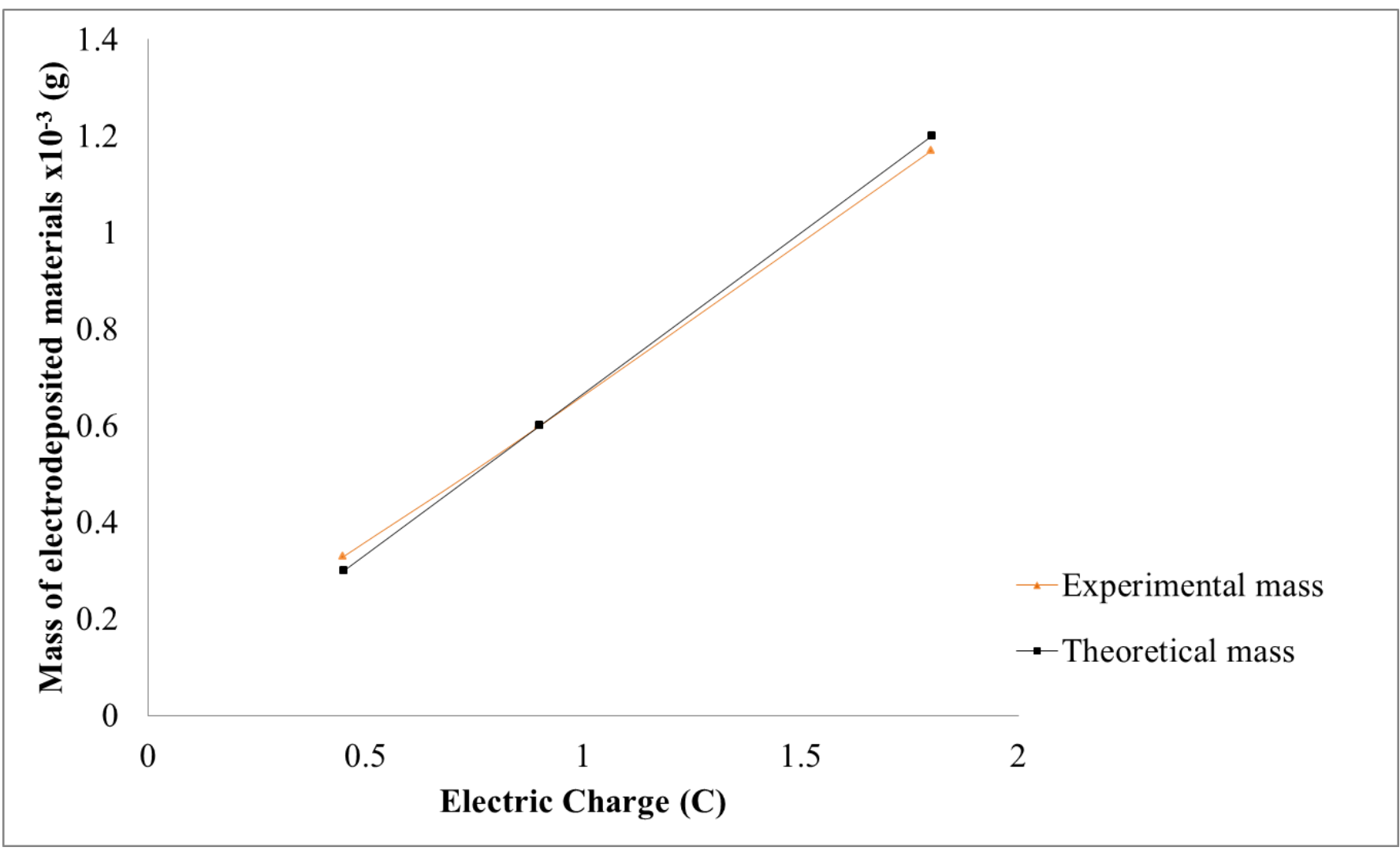

Figure 1: Relation between the mass of electrodeposited materials (g) (experimental and theoretical one) and the electric charge $Q(C)$ at $E$ imposed $=0.6 \mathrm{~V}$ 
A

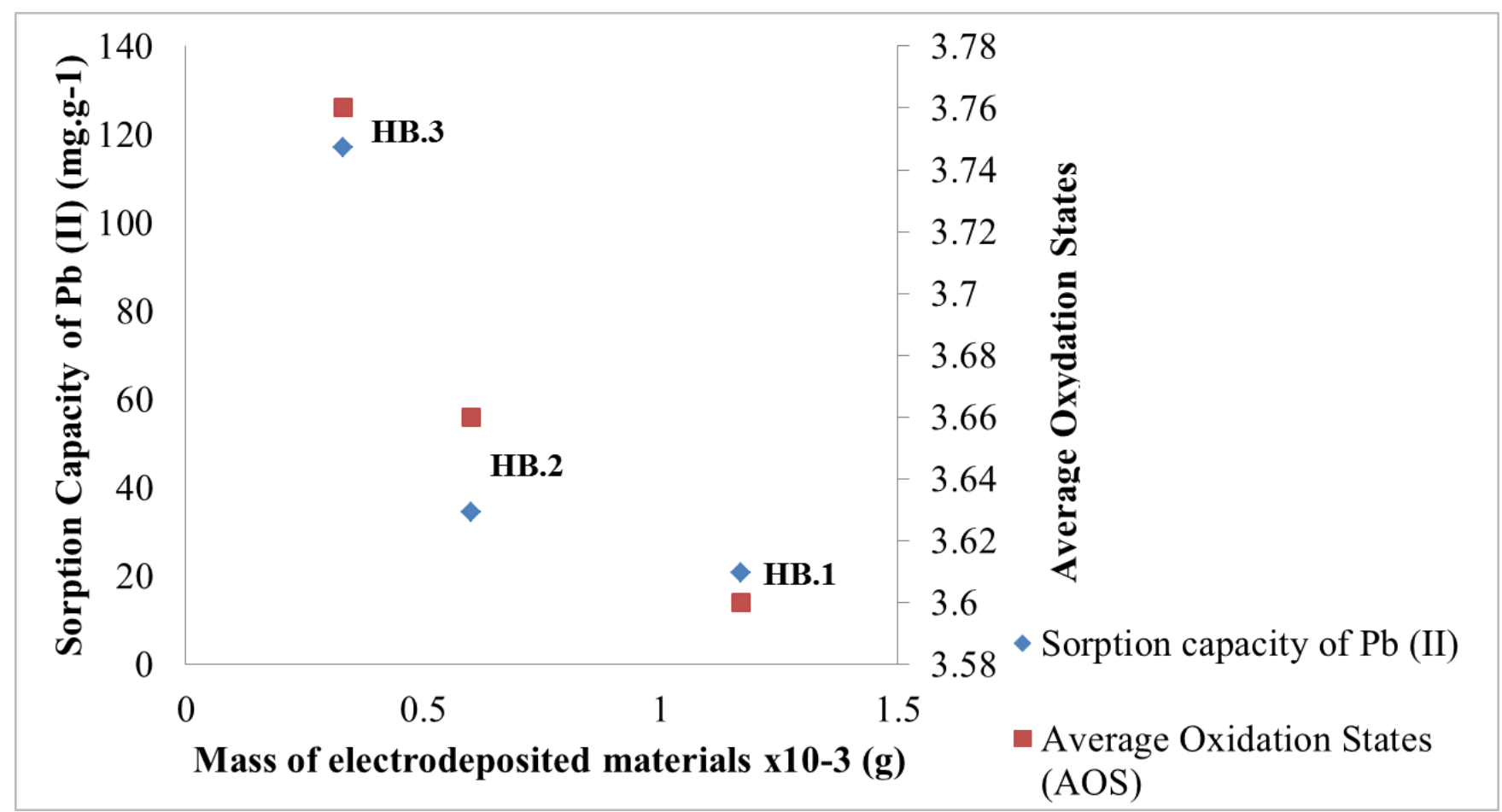

B

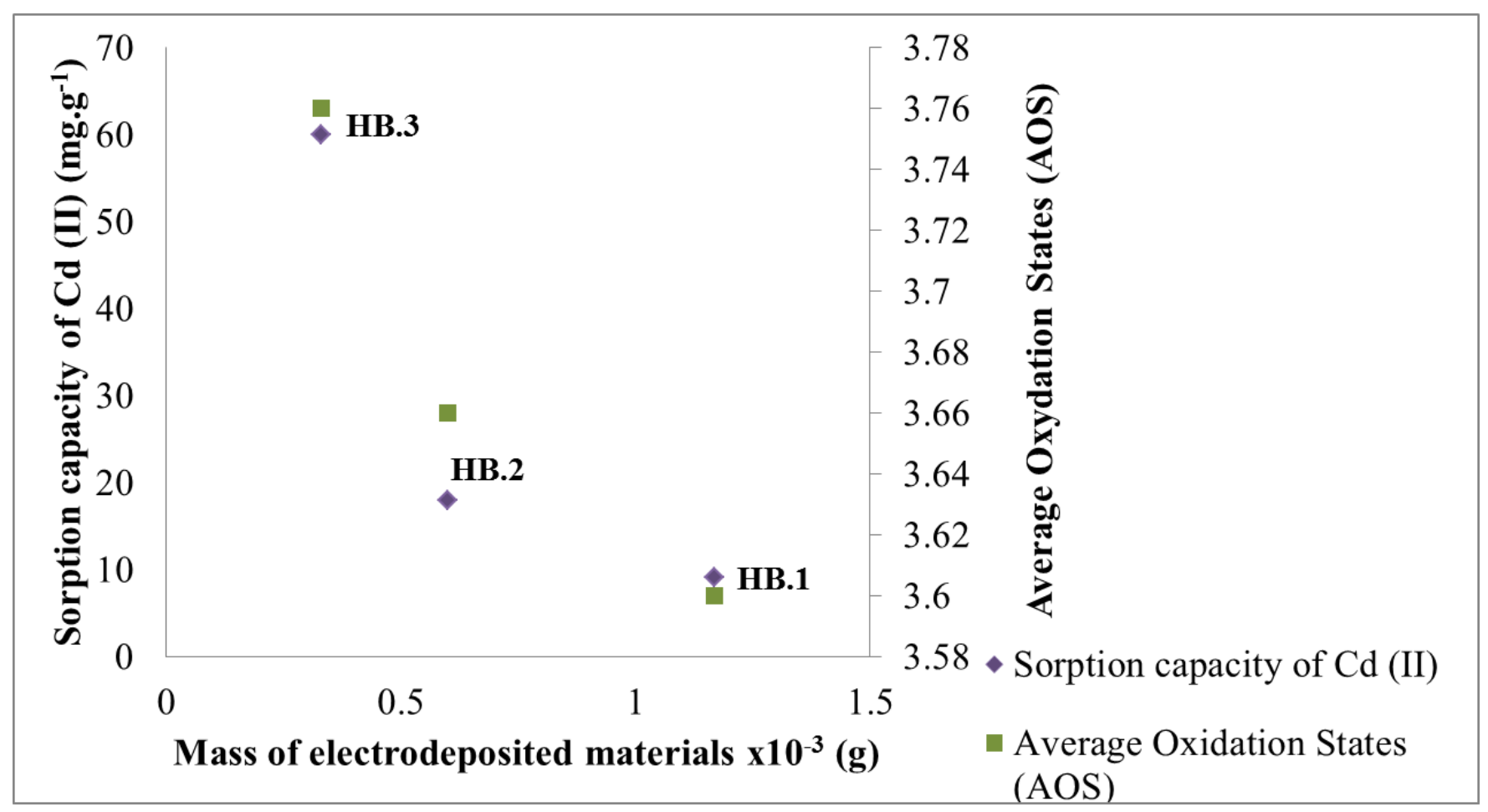

Figure 2: Sorption capacity of each sample of birnessite thin film (mg.g $\left.{ }^{-1}\right)$ in function of their mass (mg) and their AOS: A- for Pb (II); B- for Cd (II) 


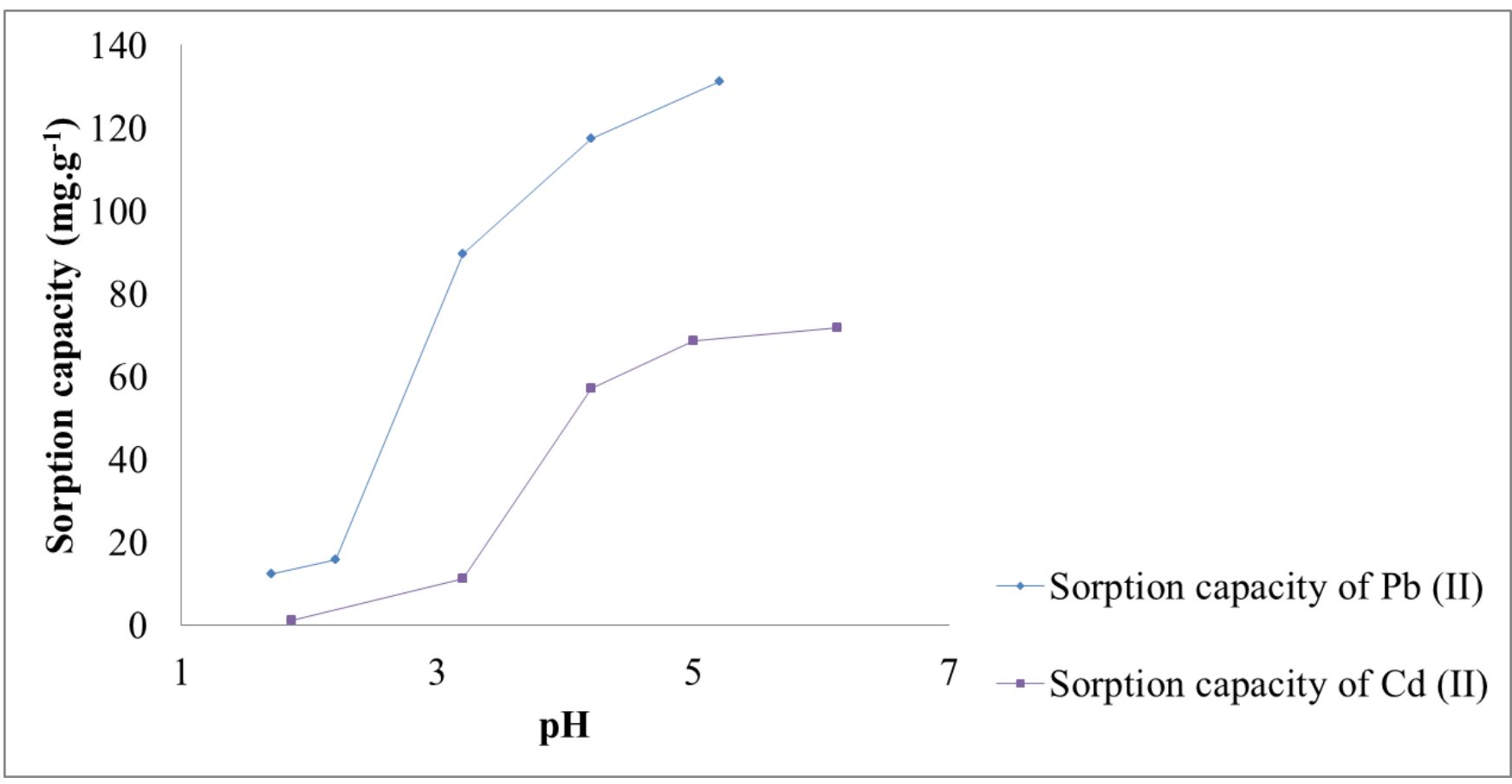

Figure 3: Sorption capacity (mg.g ${ }^{-1}$ ) of $\mathrm{Pb}$ (II) and Cd (II) by one birnessite thin film (HB.3) function of different initial $\mathrm{pH}$ values. 


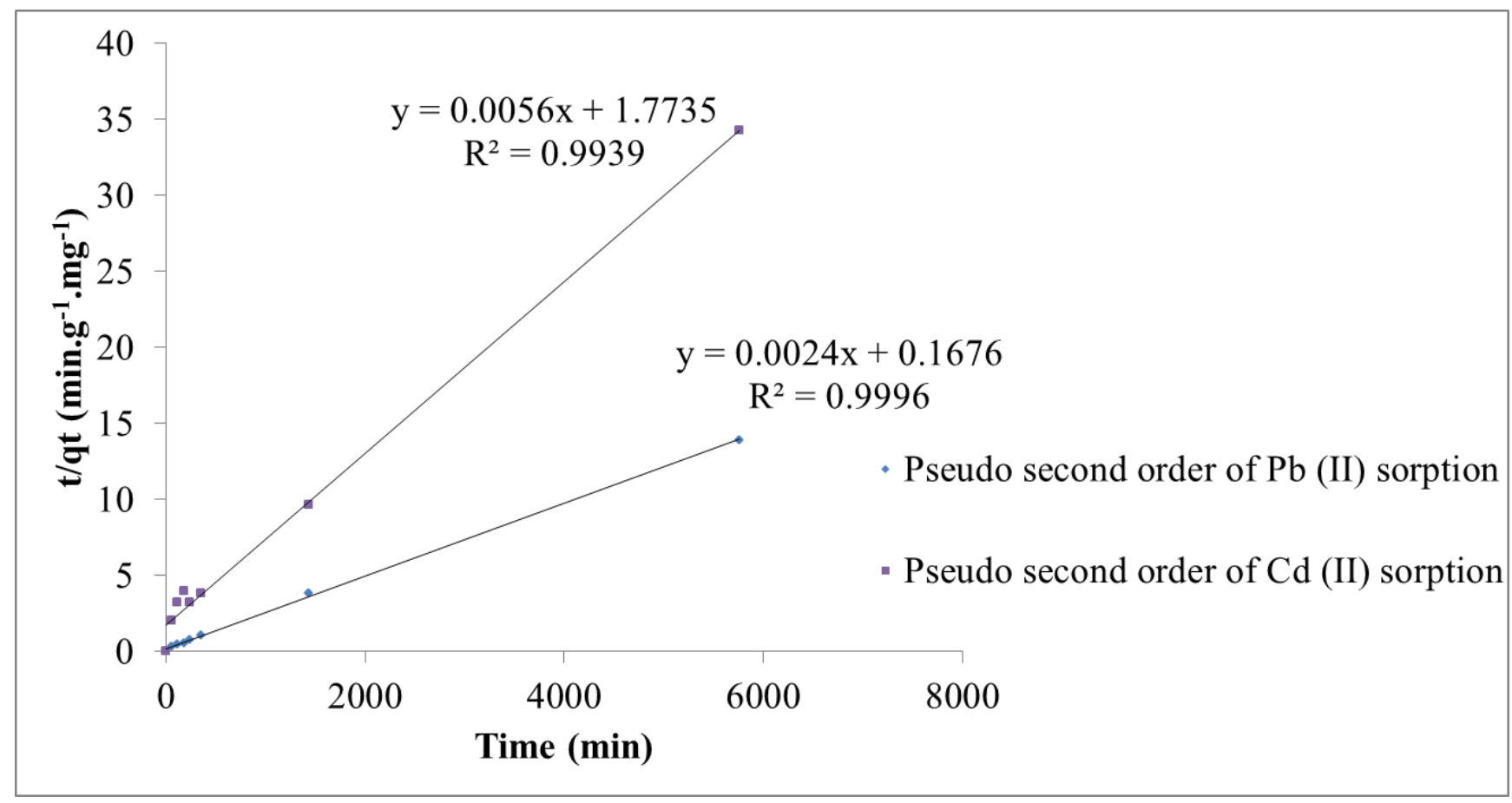

Figure 4: Kinetic models for the sorption of $\mathrm{Pb}$ (II) and $\mathrm{Cd}$ (II) by one birnessite thin film (HB.3) 
$\mathbf{A}$

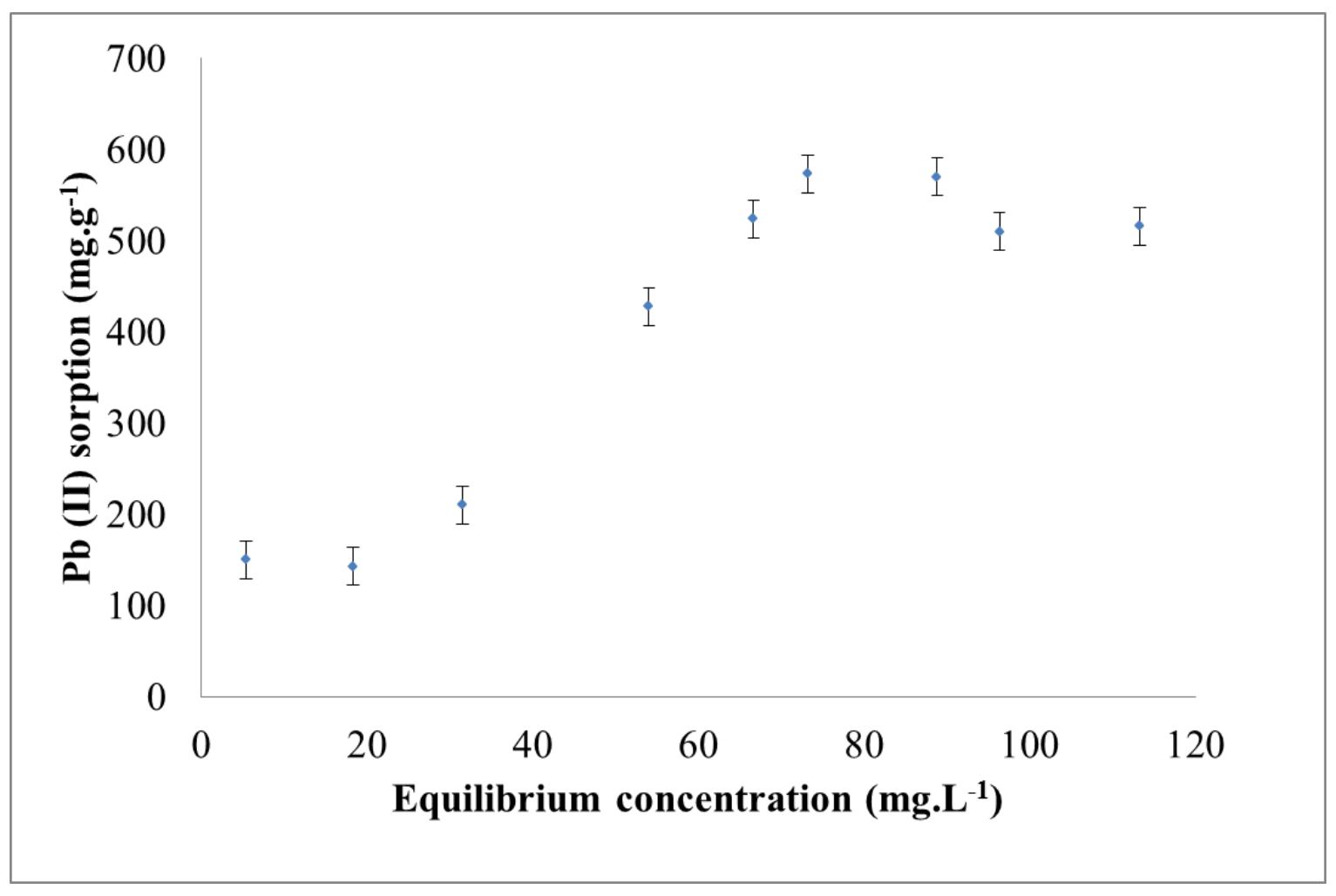

B

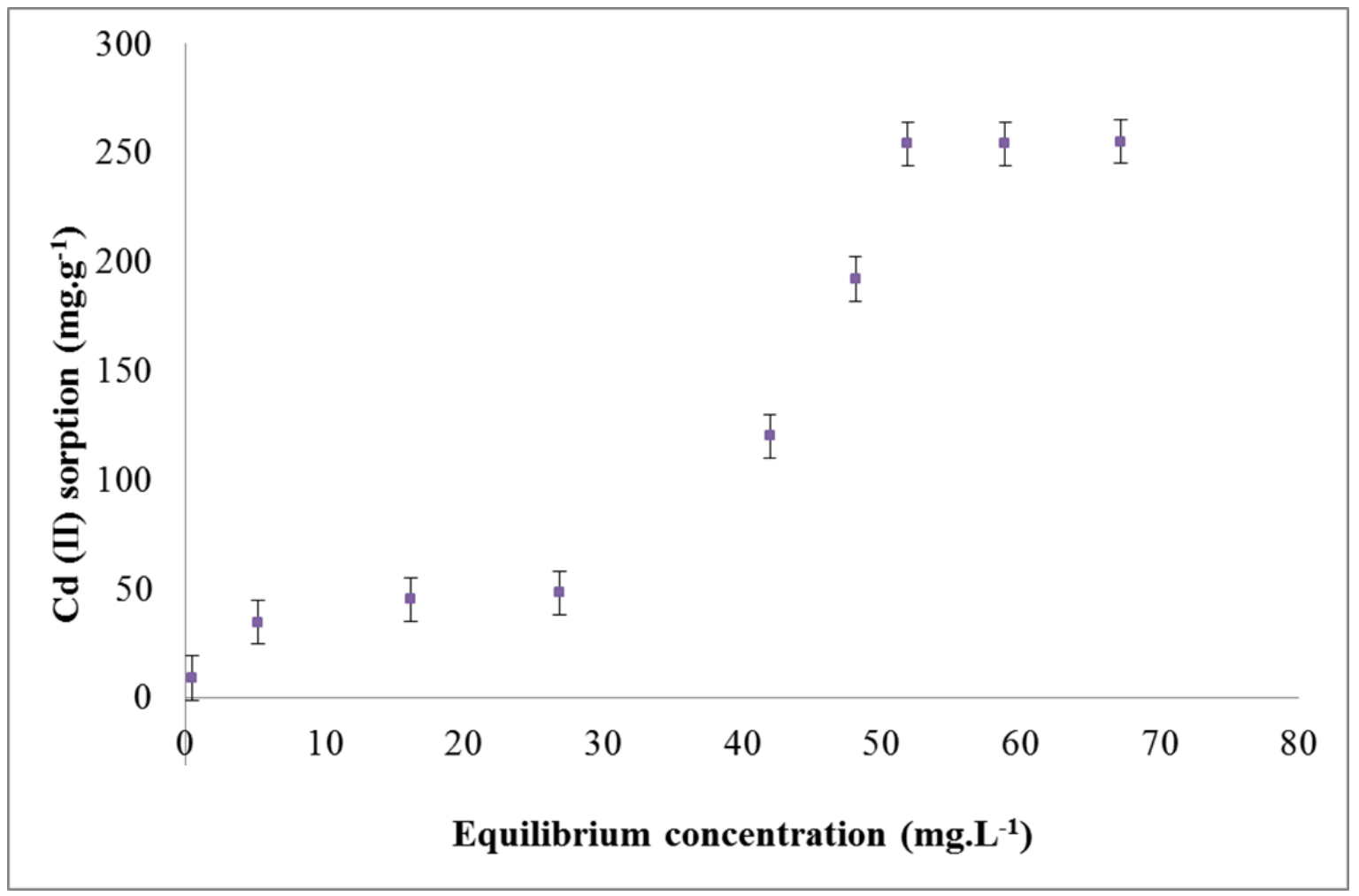

Figure 5: Sigmoid isotherm plot for the adsorption onto birnessite thin film (HB.3) of $\mathrm{A}-\mathrm{Pb}$ (II) and B- Cd (II) 


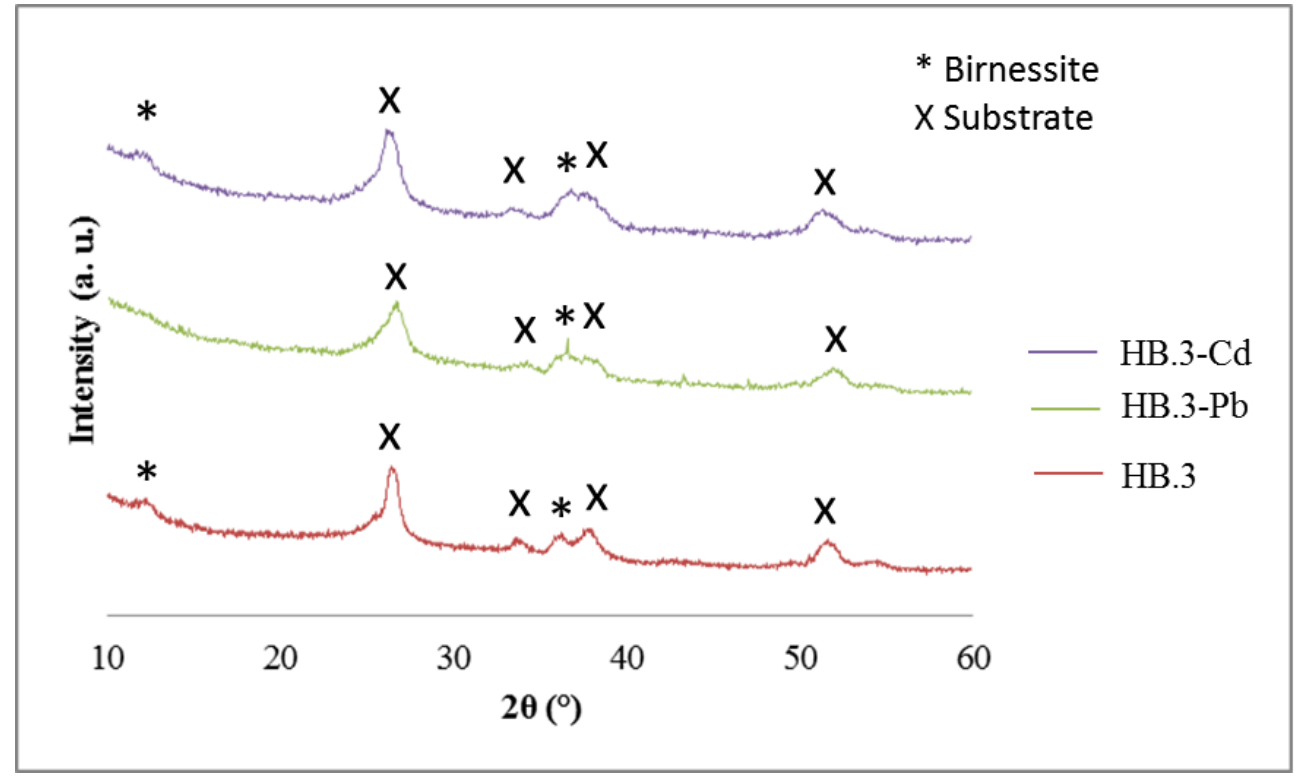

Figure 6: GIXRD patterns of birnessite thin films $\mathrm{HB} .3$ before and after sorption of $\mathrm{Pb}$ (II) (HB3.-Pb) and Cd (II) (HB.3-Cd) 


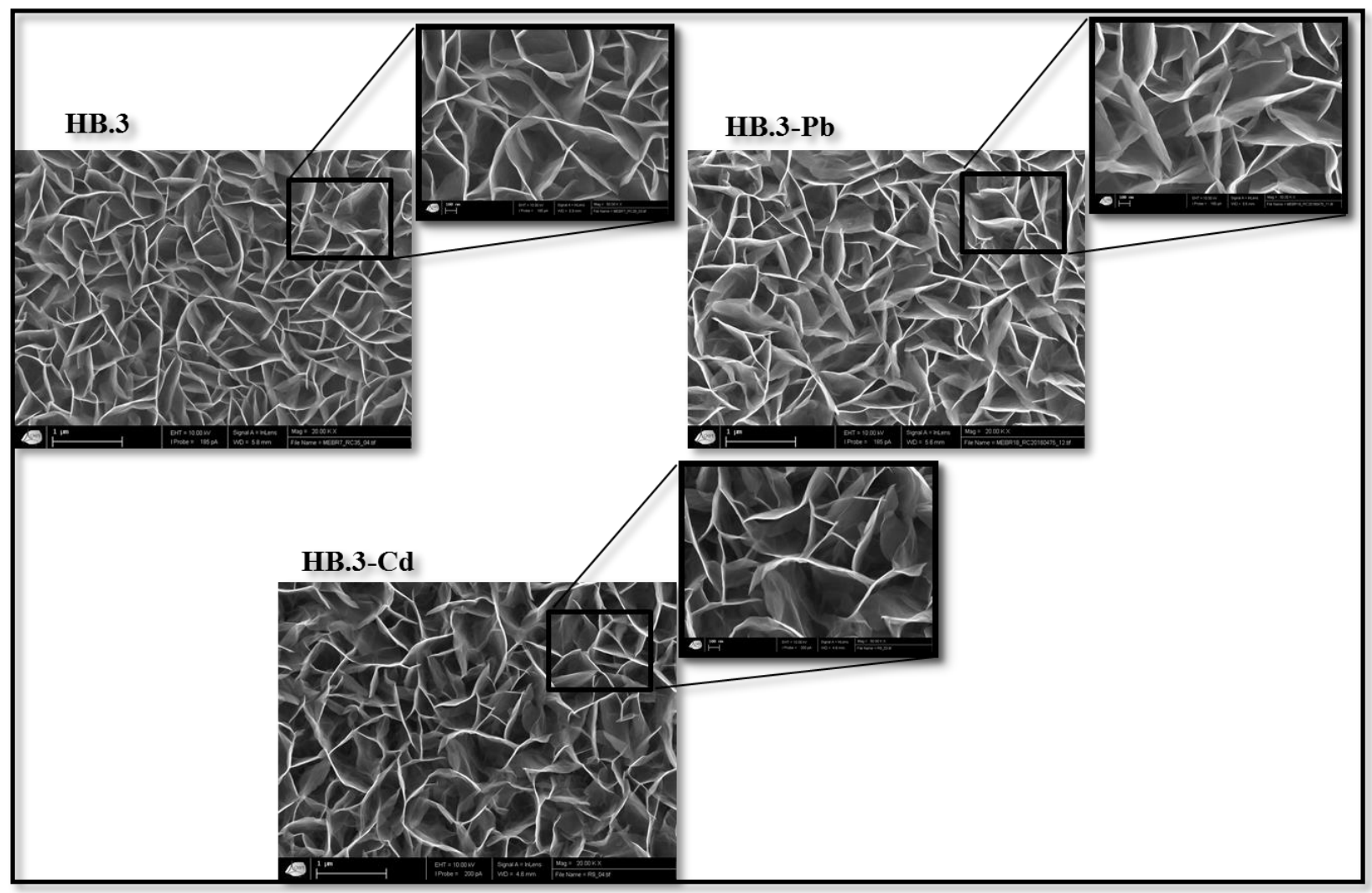

Figure 7: SEM images of birnessite thin films (HB.3) before and after sorption of Pb (II) (HB.3-Pb) and Cd (II) (HB.3-Cd) (magnifications: 3000 and 20000) 


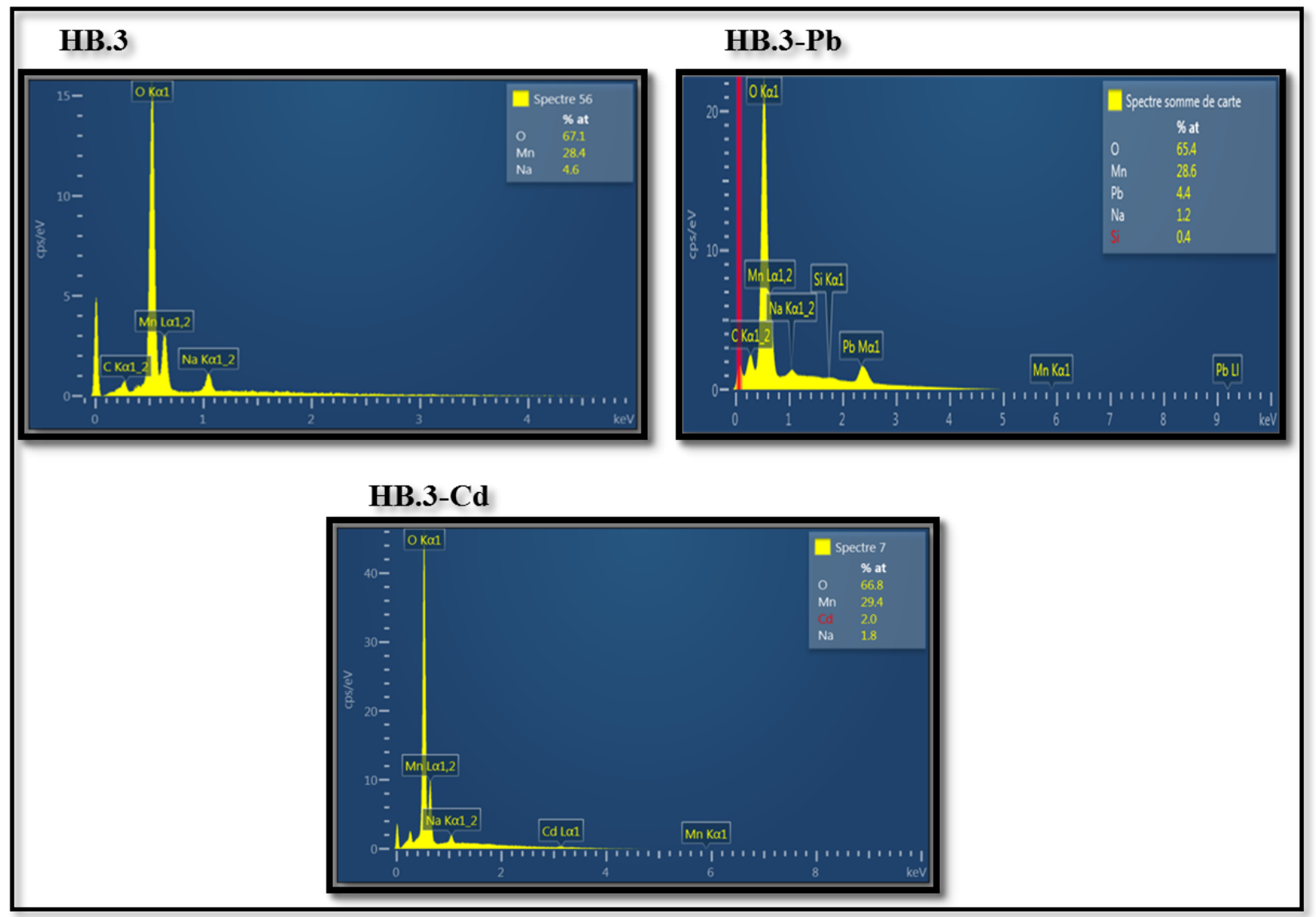

Figure 8: EDS analyses of birnessite thin films (HB.3) before and after sorption of $\mathrm{Pb}$ (II) (noted HB.3-Pb) and Cd (II) (noted HB.3-Cd) 
HB.3-Pb
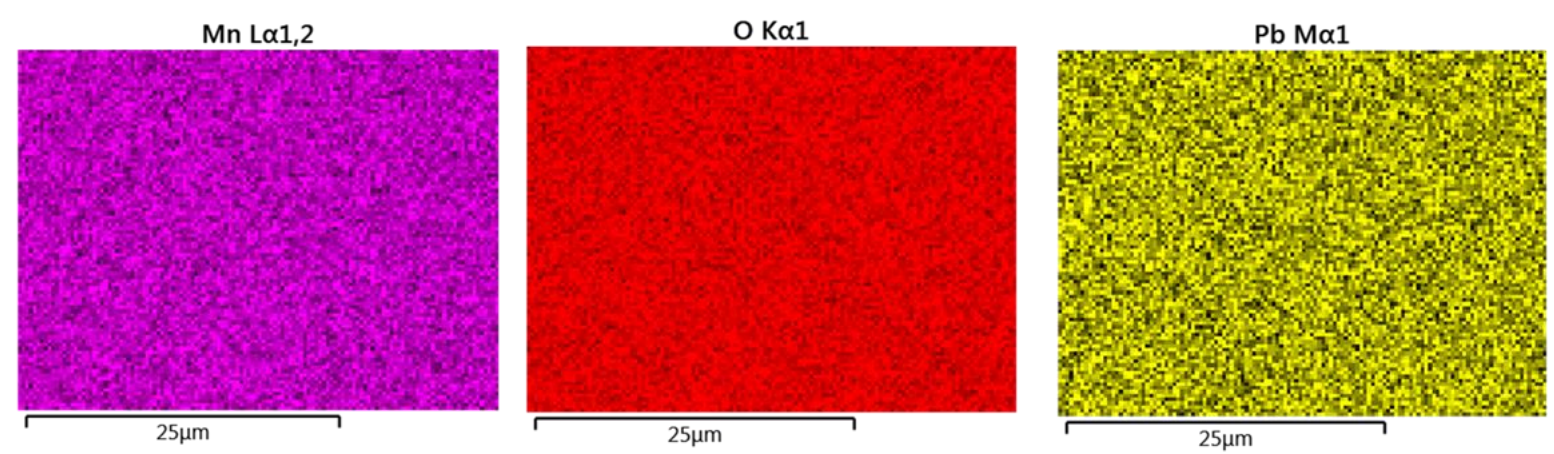

HB.3-Cd

$\mathrm{Mn} \operatorname{L} \alpha 1,2$

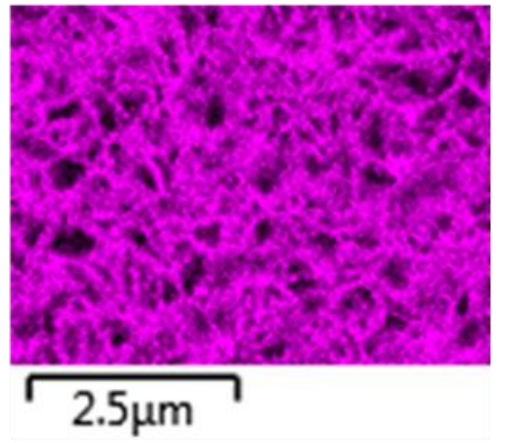

$\mathrm{O} \mathrm{K} \alpha 1$

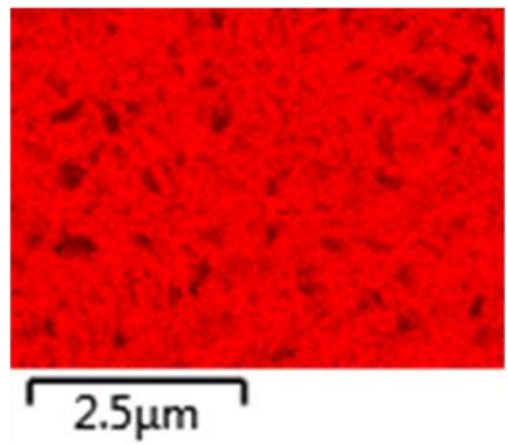

$\mathrm{Cd} \operatorname{L} \alpha 1$

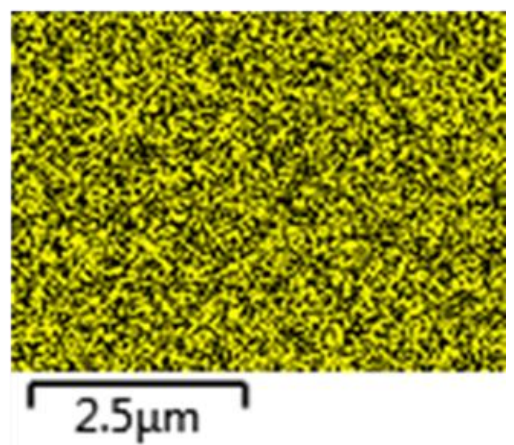

Figure 9: Elementary cartography observations of birnessite thin film after sorption of $\mathrm{Pb}$ (II) (HB.3-Pb) and Cd (II) (HB.3-Cd) 
$\mathbf{A}$

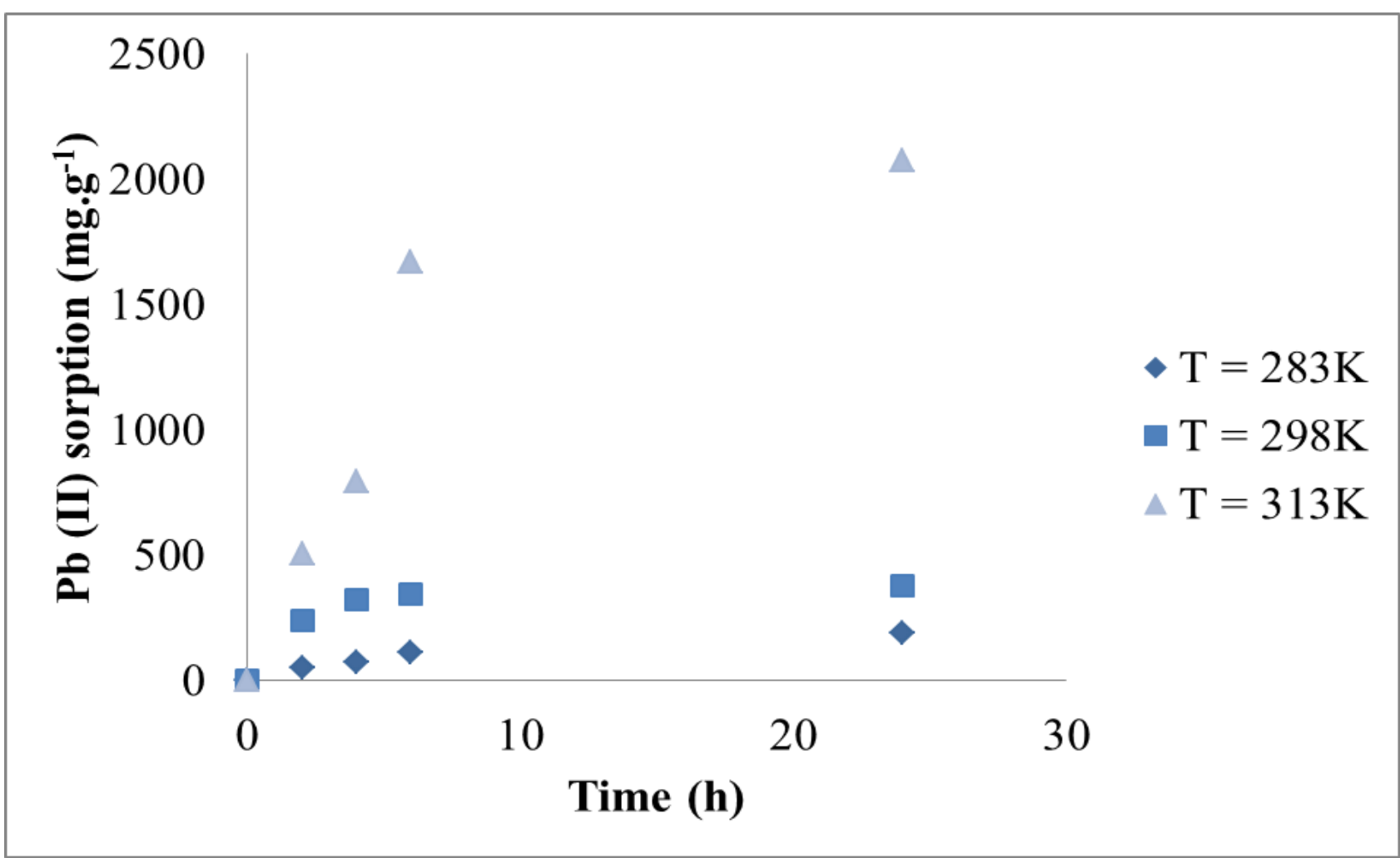

B

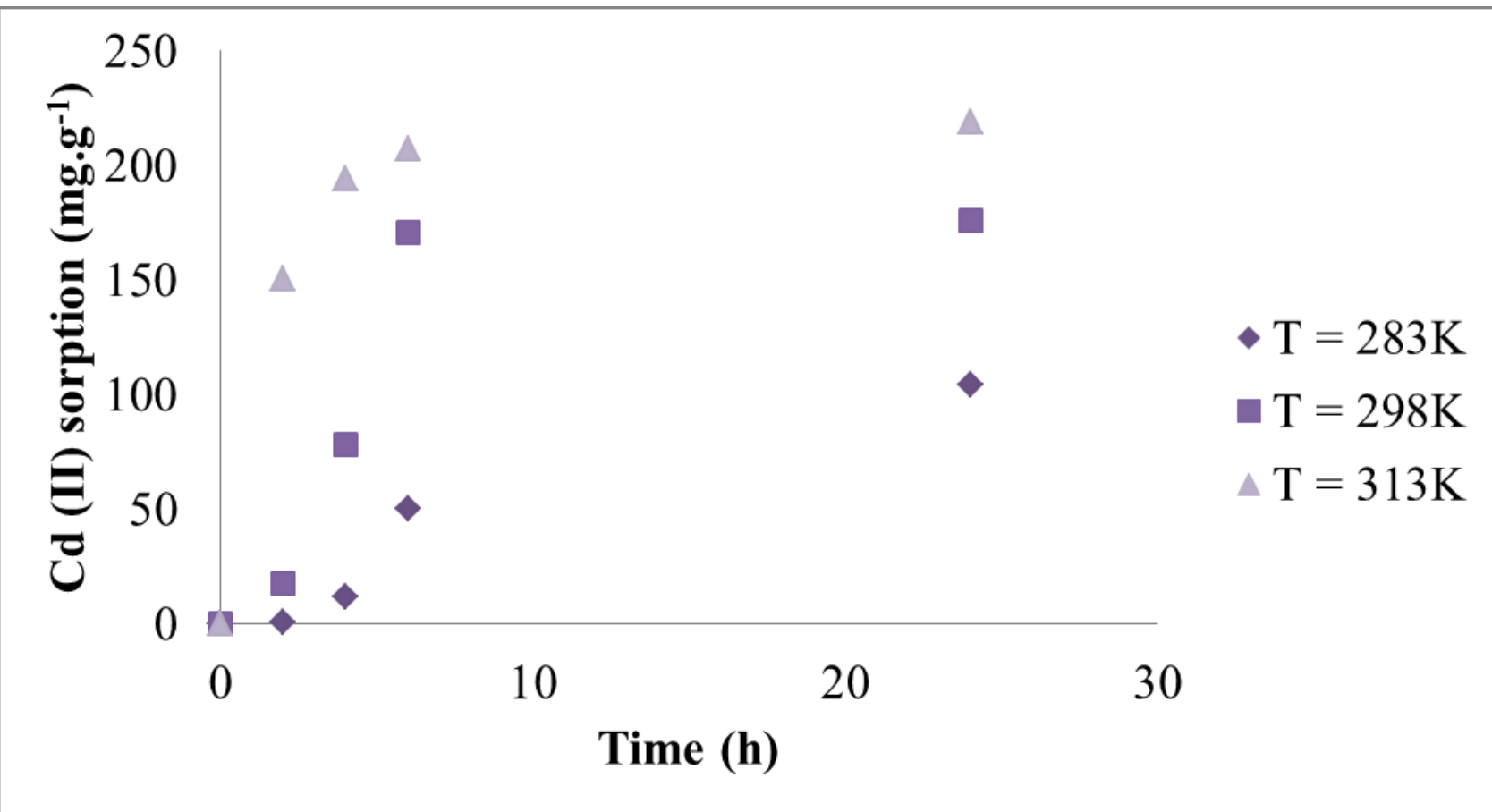

Figure 10: Sorption capacity (mg.g-1) by birnessite thin film (HB.3) as function of time (h) at different temperatures for: $\mathrm{A}-\mathrm{Pb}$ (II) and B- Cd (II) 


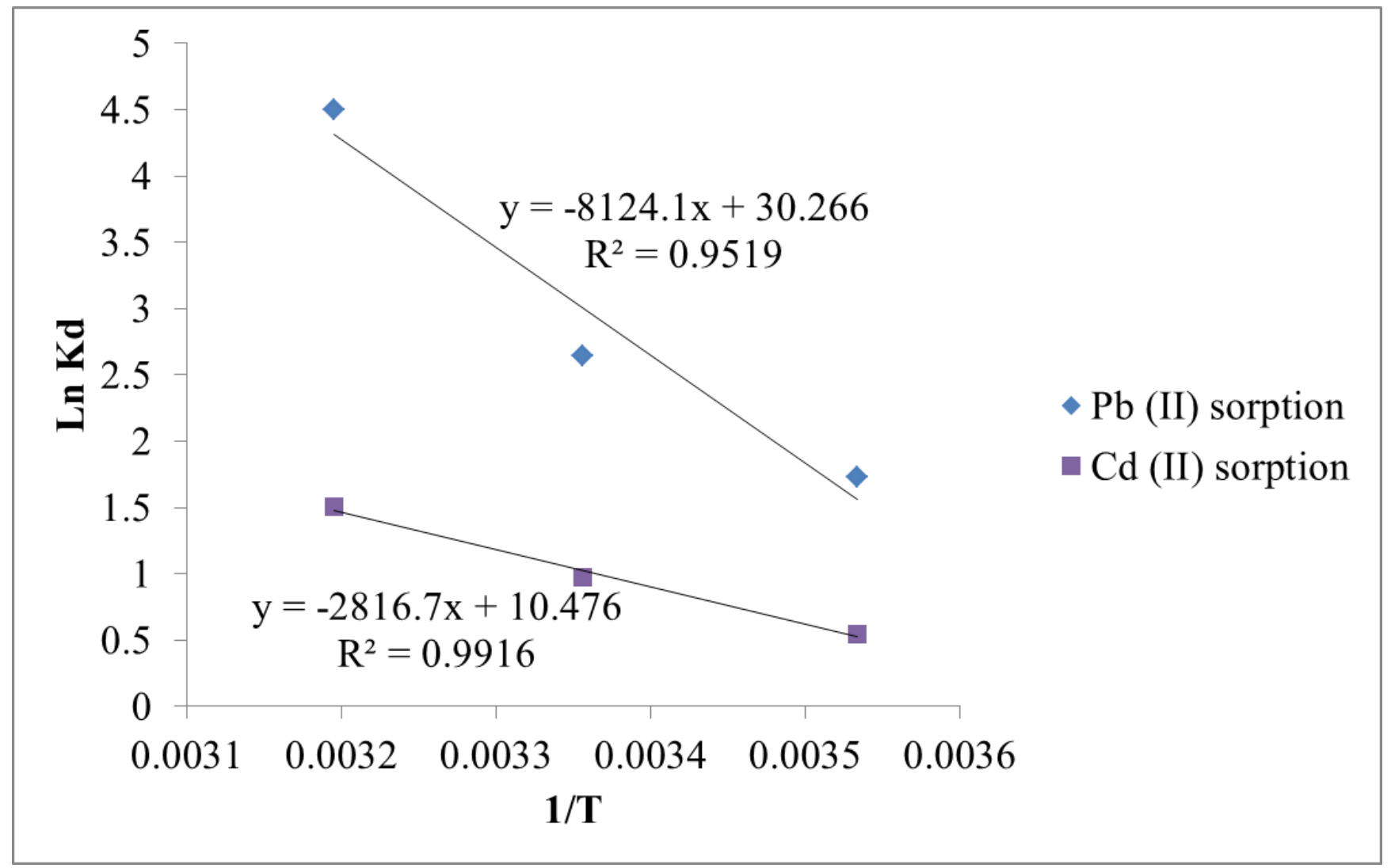

Figure 11: The Van't Hoff plots of $\mathrm{Pb}$ (II) and Cd (II) sorption onto birnessite thin film HB.3 
A-

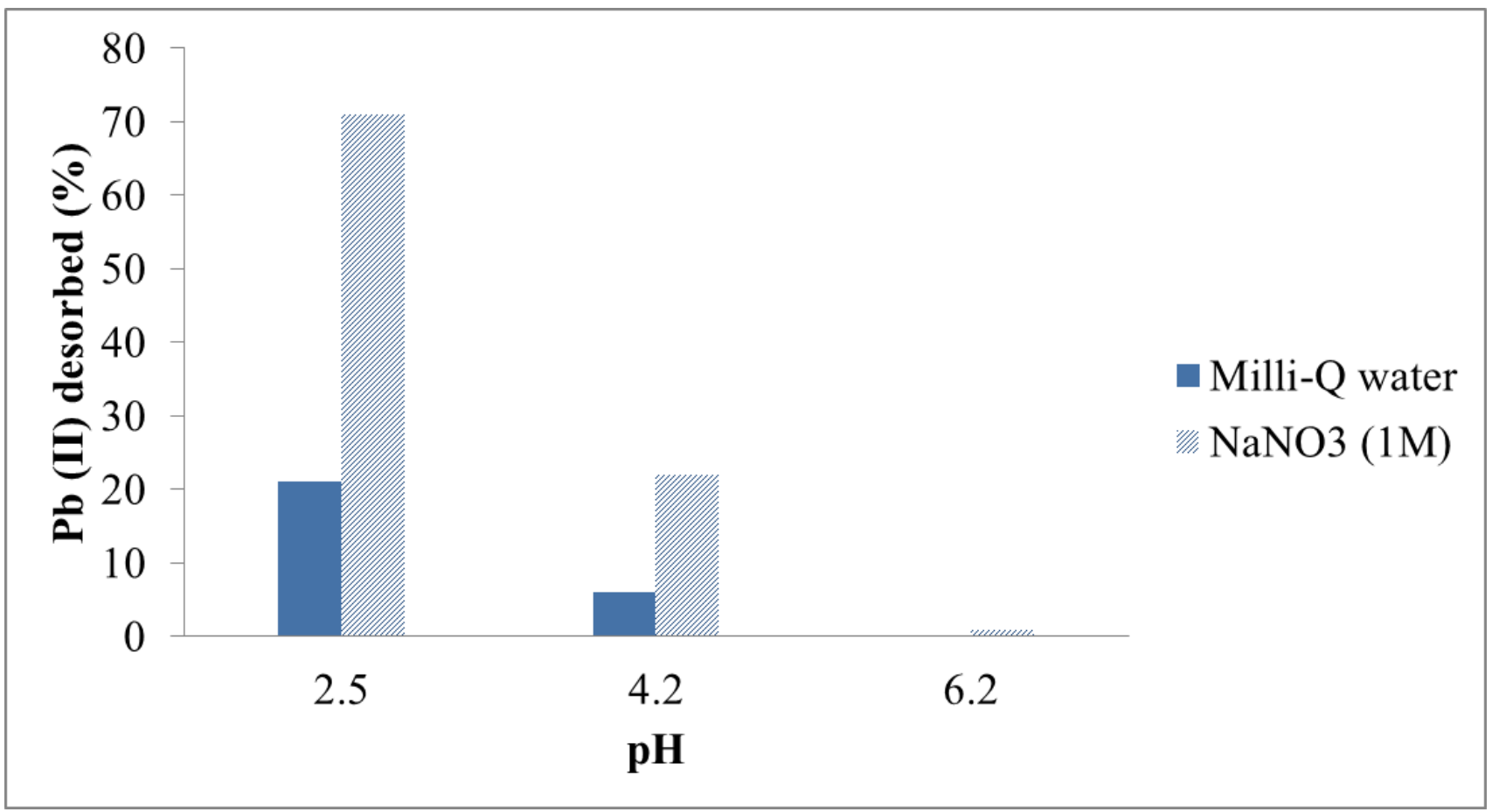

B-

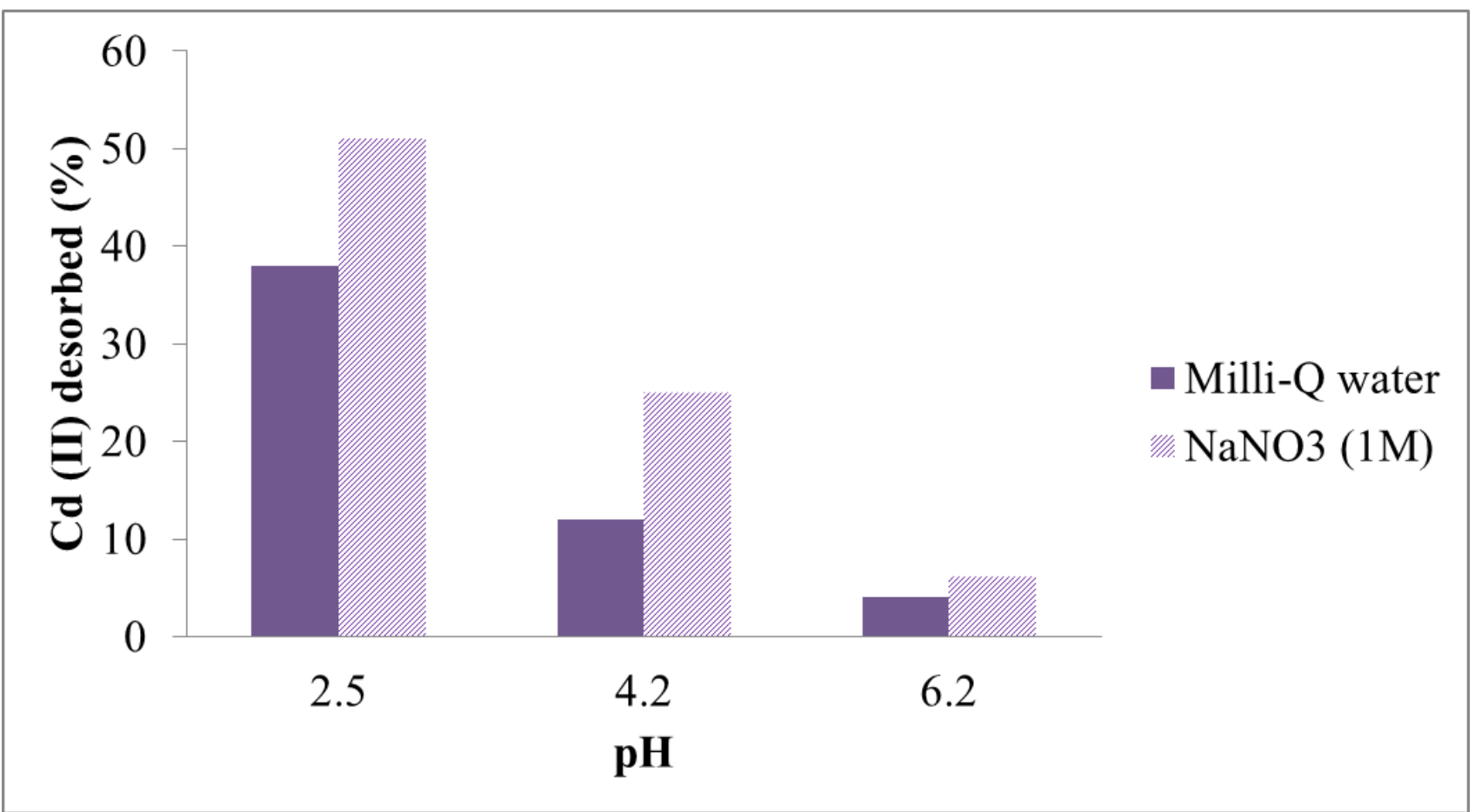

Figure 12: Desorption (\%) from birnessite thin film (HB.3) in function of medium and pH for: A- Pb (II) and B- Cd (II). 


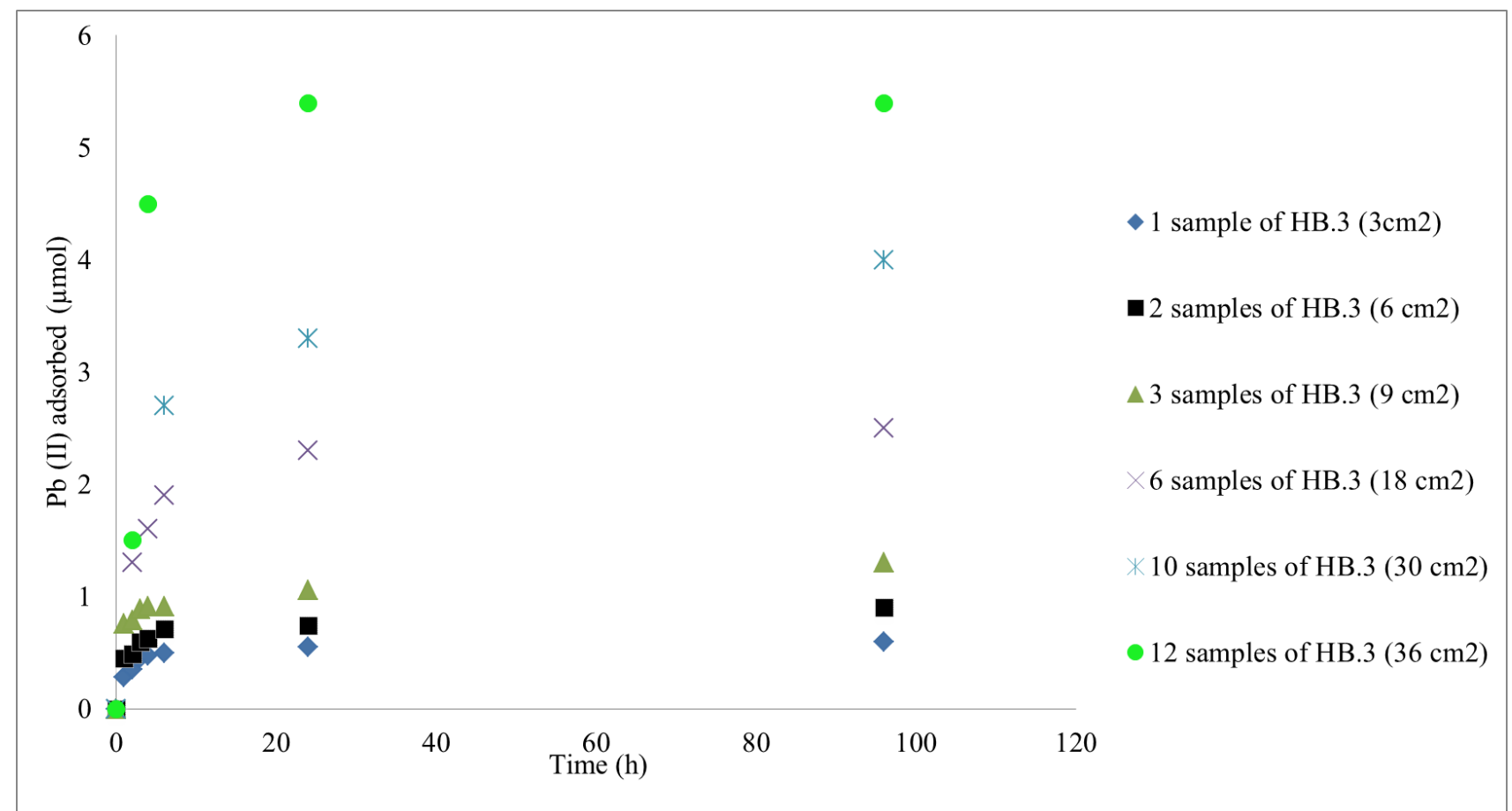

Figure 13: Amount of $\mathrm{Pb}$ (II) adsorbed ( $\mu \mathrm{mol}$ ) by increasing the number of sample (HB.3) as the function of time (h) 